\title{
East Asia's Democratic Developmental States and Economic Growth
}

\author{
Michael T. Rock
}

\begin{abstract}
Political elites in East Asia have opted for a set of democratic institutions with a strong majoritarian bias that privilege efficiency and accountability over representativeness. Some have labeled these democracies "democratic developmental states." Because the political architects of East Asia's democratic developmental states have met at least some of their objectives, it is time to ask, What has been the impact of the shift to majoritarianism on growth? I answer this question empirically by demonstrating that the contribution to growth from majoritarian democratic institutions in East Asia is as large as that from the region's developmentally oriented authoritarian governments. KEYwords: East Asia, democracy, growth, developmental autocracy, developmental democracy, majoritarian democracy
\end{abstract}

THERE IS AMPLE EVIDENCE THAT POLITICAL ELITES IN EAST ASIA'S DEmocracies have crafted democratic institutions with a distinct majoritarian thrust (Reilly 2006). ${ }^{1}$ White (2006) and Robinson and White (1998) have suggested that these kinds of democracies presage the emergence of democratic developmental states or democratic governments that are more effective in delivering public goods and growth, but that are also decidedly less representative of the range of interests extant in many, if not most, polities, particularly those with multiethnic and/or multireligious communities. The hallmarks of the selective political reforms of democratic institutions in East Asia include adoption of some combination of more majoritarian electoral systems (Reilly 2006, 109-112), political party systems that favor the institutionalization of a small number of large bridging parties (Reilly 2006, 131-142), and forms of executive government that increase government stability (Reilly 2006, 146-166).

The question I raise here is, Have East Asia's majoritarian democracies been able to sustain growth rates comparable to those of the region's developmentally oriented autocracies? Empirical findings 
indicate that the region's democratic developmental states have contributed as much to growth as the developmentally oriented authoritarian regimes that ushered in East Asia's economic miracles (World Bank 1993). The argument that follows is in four parts. The first section reviews the literature on the impact of more majoritarian democratic institutions on development policies thought to affect growth. The next section formally tests the hypothesis that East Asia's democratic developmental states contributed to growth in an East Asian region cross-country "difference-in-difference" panel regression framework that corrects for heteroskedasticity, serial correlation, and endogeneity in right-hand side regressors. A penultimate section develops a country case study of the causal mechanisms linking the emergence of more majoritarian democratic political institutions to development policies and growth in Indonesia, a country that underwent significant regime change from a developmental autocracy to a more majoritarian democracy. The final section presents conclusions.

\section{Does the Structure of Democratic Institutions Matter? Theory and Evidence}

A growing body of theoretical, statistical, and case evidence suggests that the structure - electoral rules, party systems, and forms of executive government - of democratic institutions matters. As Persson and Tabellini $(2005,12)$ argue, three distinct research traditions have demonstrated how political institutions matter. Literature in comparative politics, summarized by Reilly (2006, chapter 4 ), shows how choice of electoral rules, party systems, and forms of executive government affect the trade-off between the representativeness of democratic institutions and the effectiveness and accountability of those institutions. A second line of research best exemplified by Haggard and Kaufmann (1995) uses comparative case studies to link the adoption of macroeconomic and trade policy reforms to the nature of party systems and forms of executive government. A third line of research, typified by Persson and Tabellini $(2005,2000)$, models the political process as a delegation game between voters and politicians and demonstrates how changes in the structure of democratic institutions affect several economic policies.

Each of these research traditions, along with that of Strom, Muller, and Bergman (2006) and Strom (2002), on delegation and accountability in parliamentary institutions, offers important insights into the possible effects of democratic institutional design on economic policies 
thought to affect growth. As Reilly (2006) demonstrates, all democratic governments must balance a trade-off between representativeness and accountability. Those favoring more representative institutions, ones that facilitate a more direct translation of popular preferences into public politics, tend to favor consociational democratic practices (Lijphart 1968) such as building political parties around ethnic, religious, or regional cleavages; using proportional electoral rules; and creating oversized or grand cabinets. Those favoring more effective government tend to opt for more majoritarian democratic institutions-majoritarian electoral rules; formation of a small number of larger bridging parties that aggregate interests across ethnic, religious, and regional lines; and forms of executive government that enhance political stability. While one line of research on this topic focuses on the unavoidable trade-offs in constitutional rules between the representativeness and accountability of political systems (Persson and Tabellini 2005, 12), another involves linking differences in institutional design to differences in economic policies (Persson and Tabellini 2005, 13).

Haggard and Kaufmann (1995) build on the latter to offer important insights into the effectiveness of more majoritarian democracies. They do so by focusing on how political institutions in crisis and noncrisis economic environments in new and existing democracies affect the ability of democratic governments to adopt macroeconomic and trade policy reforms. They argue that democratic governments in developing economies are likely to find it difficult to enact reforms if they can't overcome collective action dilemmas, avoid distributive pressures, or adopt longtime horizons in the face of short electoral cycles (Haggard and Kaufmann 1995, 156-159). These problems are likely to be acute if crises are severe, economic distortions are large, and the gains from reform are slow to emerge (Haggard and Kaufmann 1995, 159-162). In this instance, macroeconomic and trade policy reforms usually require the imposition of large losses on powerful groups in civil society before those who would benefit from the reforms are mobilized to support them. Given these problems, Haggard and Kaufmann show that successful adoption of reforms hinges on the degree of institutionalization of political party systems and executive power $(1995,163-170)$. When party systems are fragmented or highly polarized, as they tend to be in consociational democracies, and executives are weak (as in minority coalition parliamentary governments) or isolated (as in lame-duck presidents), governments have a difficult time adopting reforms. 
Persson and Tabellini $(2000,2005)$ reinforce these findings by using formal economic models in two steps: In the first (2000), they theoretically model the relationships between political institutions and economic outcomes; in the second (2005), they subject their formal models to rigorous econometric tests. They too see a rather stark trade-off between the representativeness and accountability of different electoral rules and forms of government. As Persson and Tabellini $(2000,12)$ say, plurality electoral rules and presidential governments lean heavily toward accountability because they tend to concentrate power in a few well-institutionalized parties and in a single executive office, while proportional electoral rules and parliamentary governments lean toward representativeness since such governments are often burdened with holding together heterogeneous coalitions.

They use this insight to theoretically demonstrate that several policy variables thought to affect growth, such as the size of government, welfare programs, and fiscal deficits, will be smaller under plurality electoral rules (i.e., both the size of government and fiscal deficits will be smaller) and presidential governments (i.e., the size of government and welfare programs) than under proportional representation (PR) electoral rules and parliamentary governments (Persson and Tabellini 2000, 252-253; 2005, 31). ${ }^{2}$ Persson and Tabellini (2005) provide ample empirical support for these hypotheses. In fact, they show that a switch from PR to majority elections reduces government expenditures as a share of gross domestic product (GDP) by 5 percent, welfare spending by $2-3$ percent, and fiscal deficits by about 2 percent (Persson and Tabellini 2005, 270). Additionally, they show that majority elections cut tax and spending by about 0.5 percent of GDP prior to elections, while PR elections increase welfare spending by 0.2 percent prior to elections (Persson and Tabellini 2005, 271). In a subsequent paper, Persson and Tabellini (2006, 321-322) show that presidential democracies grow faster than parliamentary ones and that new majoritarian presidential democracies cut government spending as a share of GDP by almost 2 percent, while new parliamentary democracies that use proportional electoral rules raise government spending, leading to a difference in public spending of 5 percent of GDP.

\section{Data and Hypothesis Tests}

In light of both the theory and empirical evidence described above, what follows is a set of hypothesis tests of the effects of more 
majoritarian democratic political institutions on growth. Hypothesis tests are limited to the eleven East Asian polities (see Appendix Table 3) for which data are available, including the eight that adopted more majoritarian democratic political institutions. By focusing on East Asia it becomes possible to directly compare, via a difference-indifference empirical testing strategy, the impact of some of these polities' developmentally oriented autocratic political institutions on growth with the impact of their more majoritarian democratic political institutions. Such a comparison begins to answer our central question: Has the shift in underlying political institutions from developmentally oriented autocracies to majoritarian democracies affected growth? The answer provides a tough and critical comparative test of the impact of majoritarian institutions on growth in East Asia.

Hypothesis tests are rooted in an admittedly, but commonly used, reduced form fixed-effects country panel regression model, or what $\mathrm{Pa}$ paioannou and Siourounis $(2008,6)$ label a "difference-in-difference" model where some "countries are the "treated' group while [other] ... countries ... serve as the "control' group." In this instance, some countries and country years (for majoritarian democracies and for developmental autocracies) ${ }^{3}$ are the treated groups while other countries and country years are the control group. ${ }^{4}$ This kind of model is becoming increasingly popular among economists (Rodrik and Wacziarg 2005; Papaioannou and Siourounis 2008) because it enables researchers to account for counterfactuals (Rodrik and Wacziarg 2005, 50), missing variables, time-invariant country characteristics, and global trends ( $\mathrm{Pa}-$ paioannou and Siourounis 2008, 6), and to control for endogeneity among right-hand side regressors (Besley and Case 2000).

Endogeneity between the right-hand side majoritarian political institutions variable and the long list of control variables is corrected for by estimating two-stage least squares (TSLS) fixed-effects country panel regressions where majoritarian political institutions are instrumented by the number of democracies in East Asia, lagged values of Przeworski et al.'s (2000) democracy variable, and Correlates of War data on country years during which a country is experiencing either an internal or external war. ${ }^{5}$ First-stage regressions suggest these variables are good instruments. ${ }^{6}$ Following Beck and Katz (1995), cross-section heteroskedasticity is accounted for by estimating panelcorrected standard errors. Serial correlation is corrected for by estimating a first-order autoregressive or AR(1) process.

The basic econometric specification is $Z_{i t}=\alpha_{i}+\Psi D_{i t}+\Gamma X_{i t}+v_{i t}$ where $Z_{i t}$ is the annual real GDP per capita growth rate of country $i$ in 
year $t, \alpha_{\mathrm{i}}$ captures country-specific fixed effects, $D_{i t}$ is a dummy variable measure of majoritarian political institutions (where $M A J_{i t}=1$ in country years of majoritarian democracy and $M A J_{i t}=0$ otherwise), and $X_{i t}$ is a vector of control variables. When available, data are from 1950 to $2009 .^{7}$ The control variables include the number of democracies in the world $\left(N D W_{i t}\right)$ to account for democracy's Third Wave (Huntington 1991), a standard set of economic variables: relative income per capita $\left(R E L Y N U S_{i t}\right)$, investment as a share of GDP $\left(K I_{i t}\right)$, the population growth rate $\left(P O P G_{i t}\right)$, government consumption expenditures as a share of GDP $\left(K G_{i t}\right)$, openness to trade or the trade ratio- [(exports + imports)]/GDP or $O P E N K_{i t}$, the deviation of the investment price index from its mean (PIDEV $\left.V_{i t}\right)$, and a discrete set of other dummy variables measuring other aspects of either democracy or autocracy $\left(D O A_{i t}, A U T_{i t}, D E M_{i t}\right.$, and $\left.S E M D E M_{i t}\right)$ defined below that distinguish the effects of majoritarian political institutions from other potentially important aspects of democratic and autocratic political institutions.

Because Taiwan is included in the analysis and the Penn World Tables are the only good dataset available that includes Taiwan, all of the economic variables are from Penn World Tables (see Appendix Table 1). While a long list of economic variables has been used in growth regressions, I adopt the most commonly used ones (Levine and Renelt 1992; Barro 1991). My empirical research strategy guided my choice of political institutions variables. First, I test the hypothesis that regime type (autocracy/democracy) affects growth in East Asia. Because neither autocracy nor democracy is ever statistically significant (see Table 1), I then test the hypothesis that the form of autocracy (whether it is developmentally oriented) and the form of democracy (whether it is majoritarian) affect growth. This key critical test asks the question, How has the shift to majoritarian democracy affected growth, particularly when compared to countries' developmental autocracies?

Finally, I carry out three different kinds of robustness tests. First, each paired democracy/autocracy variable is subject to six separate regressions in which the number of control variables is increased and equations are adjusted for endogeneity. In addition, I develop two distinct measures of $M A J$ to ensure that I am not biasing empirical results in favor of $M A J$. Finally, I test for the impact on growth of developmentally oriented autocracies with three other democracy measurespure democracy $(D E M)$, semidemocracy $(S E M D E M)$, and the quality of democracy as measured by the Polity 2 variable (POLITY2) in Polity IV (Marshall and Jaggers 2008). Country year coding for each 
Table 1 East Asian Growth Panel Regressions on Autocracy (AUT) and Democracy (DEM) with Panel Corrected Standard Errors (no degree of freedom correction)

\begin{tabular}{|c|c|c|c|c|c|c|}
\hline $\begin{array}{l}\text { Independent } \\
\text { Variables }\end{array}$ & OLS & TSLS & OLS & TSLS & OLS & TSLS \\
\hline $\mathrm{C}$ & 3.22 & -2.55 & -1.54 & -5.91 & -1.76 & -4.30 \\
\hline RELYNUS & & & $\begin{array}{c}-.05 \\
(-2.26)^{* *}\end{array}$ & $\begin{array}{c}-.09 \\
(-.83)\end{array}$ & $\begin{array}{c}-.05 \\
(-1.60)\end{array}$ & $\begin{array}{l}-.10 \\
(-.74)\end{array}$ \\
\hline KI & & & $\begin{array}{c}.21 \\
(6.66)^{* * *}\end{array}$ & $\begin{array}{c}.17 \\
(2.22)^{* *}\end{array}$ & $\begin{array}{l}.21 \\
(6.42)^{* * *}\end{array}$ & $\begin{array}{c}.16 \\
(2.16)^{* *}\end{array}$ \\
\hline POPG & & & $\begin{array}{c}.48 \\
(1.36)\end{array}$ & $\begin{array}{c}1.08 \\
(1.35)\end{array}$ & $\begin{array}{c}.47 \\
(1.31)\end{array}$ & $\begin{array}{c}1.09 \\
(1.33)\end{array}$ \\
\hline $\mathrm{KG}$ & & & & & $\begin{array}{l}.03 \\
(.27)\end{array}$ & $\begin{array}{l}-.13 \\
(-.35)\end{array}$ \\
\hline OPENK & & & & & $\begin{array}{l}.005 \\
(.45)\end{array}$ & $\begin{array}{l}.01 \\
(.78)\end{array}$ \\
\hline PIDEV & & & & & $\begin{array}{c}-.01 \\
(-1.01)\end{array}$ & $\begin{array}{c}-.03 \\
(-1.53)\end{array}$ \\
\hline NDW & $\begin{array}{c}.02 \\
(1.64)^{*}\end{array}$ & $\begin{array}{l}-.01 \\
(-.09)\end{array}$ & $\begin{array}{c}.01 \\
(.80)\end{array}$ & $\begin{array}{l}.002 \\
(.05)\end{array}$ & $\begin{array}{l}-.001 \\
(-.03)\end{array}$ & $\begin{array}{l}-.03 \\
(-.70)\end{array}$ \\
\hline AUT & $\begin{array}{c}.20 \\
(.80)\end{array}$ & $\begin{array}{r}13.69 \\
(.65)\end{array}$ & $\begin{array}{l}-.21 \\
(-.28)\end{array}$ & $\begin{array}{l}8.25 \\
(1.36)\end{array}$ & $\begin{array}{l}-.21 \\
(-.27)\end{array}$ & $\begin{array}{c}8.99 \\
(1.25)\end{array}$ \\
\hline DEM & $\begin{array}{l}-1.87 \\
(-2.05)^{* *}\end{array}$ & $\begin{array}{l}5.85 \\
(.36)\end{array}$ & $\begin{array}{l}-1.11 \\
(-1.33)\end{array}$ & $\begin{array}{c}7.75 \\
(1.00)\end{array}$ & $\begin{array}{l}-.86 \\
(-.98)\end{array}$ & $\begin{array}{c}9.19 \\
(1.03)\end{array}$ \\
\hline AR (1) & $\begin{array}{c}.26 \\
(5.90)^{* * *}\end{array}$ & $\begin{array}{c}.92 \\
(3.78)^{* * *}\end{array}$ & $\begin{array}{c}.22 \\
(4.94)^{* * *}\end{array}$ & $\begin{array}{c}.63^{\mathrm{a}} \\
(1.69)^{*}\end{array}$ & $\begin{array}{c}.21 \\
(4.73)^{* * *}\end{array}$ & $\begin{array}{r}.61^{\mathrm{a}} \\
(1.63)\end{array}$ \\
\hline $\begin{array}{l}\text { Number of } \\
\text { cross-sections }\end{array}$ & 11 & 11 & 11 & & 11 & \\
\hline $\begin{array}{l}N \\
\text { Equation } \mathrm{F}\end{array}$ & $\begin{array}{c}528 \\
672 * * *\end{array}$ & 528 & $\begin{array}{c}528 \\
877 * * *\end{array}$ & 515 & $\begin{array}{c}528 \\
50 * * *\end{array}$ & 515 \\
\hline J statistic & & 2.61 & & $5.10^{*}$ & & 3.76 \\
\hline
\end{tabular}

Notes: Numbers in parentheses are $t$ values.

*Indicates statistically significant at the .10 level. ${ }^{* *}$ Indicates statistically significant at the .05 level. ***Indicates statistically significant at the .01 level.

a. indicates an $\operatorname{AR}(2)$ process.

polity for each of these political variables is provided in Appendix Tables 3 and 4.

The initial $M A J$ political institutions variable is a dummy variable $(M A J 1=1)$ for each country year identified as majoritarian by Reilly (2006) and the case literature listed in Appendix Table 3. Because Singapore (Haggard 1990; Huff 1997) and Malaysia (Jomo 2007, 1986; Khoo 2003, 1995; Rock and Sheridan 2007) have sometimes been referred to as developmental autocracies, semidemocracies (Case 2002), or simply autocracies (Slater 2008, 56), coding 
both as majoritarian democracies might bias results in favor of $M A J$. To correct for this potential bias, I recoded $M A J$ for Singapore and Malaysia, as $M A J 2=0$ during the period when each is treated as a developmental autocracy. This can be seen in the coding for MAJ2 in Appendix Table 3.

Because other aspects of democratic political institutions might also affect growth, a number of these are used as additional robustness tests. At least some of the literature on Southeast Asia emphasizes the region's semidemocratic political institutions (Case 2002). Because of this, I created a semidemocracy dummy variable, SEMDEM, where $S E M D E M=1$ in each country year when the POLITY2 score is less than 6 and greater than 0 and $S E M D E M=0$ otherwise. There is one important exception to this coding rule for SEMDEM: because Case (2002) considers Singapore a semidemocracy, SEMDEM = 1 for Singapore between 1965 and 2009 despite the fact that $P O L I T Y 2=-2$ for the entire period. The coding of $S E M D E M$ for each country year can be seen in Table 4 in the Appendix. To test the hypothesis that democracy or its counterpart, autocracy, affects growth, I created both a pure democracy dummy variable $(D E M)$ and a pure autocracy dummy variable $(A U T)$. Following Polity IV, $D E M=1$ if $P O L I T Y 2>$ 5 and $D E M=0$ otherwise while $A U T=1$ if POLITY $<-5$ and $A U T$ $=0$ otherwise. Finally, I captured the quality of democracy by using POLITY2 in a regression with DOA. ${ }^{8}$

With respect to autocracy in East Asia, a large body of literature suggests that a number of the autocracies there have been quite capable and committed to development (Amsden 1989; Brandt and Rawski 2008; Evans 1995; Hill 1996; Huff 1997; Johnson 1987; Jomo 2007, 2001, 1986; Liddle 1991; Muscat 1994; Rock 1995, 1999, 2003; Rock and Sheridan 2007; Thoburn 2009; Van Arkadie and Mallon 2003; Wade 1990). The literature on northeast Asia, particularly Japan, South Korea, and Taiwan, emphasizes capitalist developmental states (Evans 1995; Evans and Rauch 1999; Johnson 1987) while that on Southeast Asia emphasizes the degree to which authoritarian elites have been committed to development (Haggard 1990; Huff 1997; Jomo 1986, 2007; Khoo 1995, 2003; Muscat 1994; Rock 2003; Rock and Sheridan 2007; Thak 2007; Thoburn 2009; World Bank 1993) even though they may not be capitalist developmental states. The case literature on these polities was used to create a dummy variable for the developmentally oriented autocracies, or DOAs, of East Asia, where $D O A=1$ in any country year in which the case literature suggests a developmental autocracy and $D O A=0$ otherwise. ${ }^{9}$ Detail 
on the actual coding of $D O A$ by country year appears in Appendix Table 3. Because Singapore and Malaysia have sometimes been considered developmental semidemocracies, after initially coding both as majoritarian democracies, I recoded both as $D O A$ to reduce the possibility of biasing results in favor of $M A J$. Both the initial coding of country years for $D O A(D O A 1)$ and the subsequent recoding of country years $(D O A 2)$ can be seen in Table 3 in the Appendix.

A list of all variables used in the empirical analysis along with variable definitions, sources for each, and the coding of each country year appears in Tables 1 through 4 in the Appendix. Descriptive statistics for all variables appear in Table 1 in the Appendix. Results of estimation of a fixed-effects country reduced form "difference-indifference" model appear in Tables 1 through 5. Table 1 reports results for pure democracy $(D E M)$ where the primary political institutions control variable is pure autocracy $(A U T)$. Empirical results in this table permit direct comparison of the impact of democracy on growth compared to autocracy.

Table 2 reports results for $M A J$ where $M A J$ is based on Reilly (2006) and the case literature identified in Appendix Table 3 and where $D O A$ is the primary political institutions control variable. ${ }^{10}$ Table 3 reports results for $M A J$ based on a more stringent coding of $M A J$ that grants more country years to $D O A$ and fewer to $M A J$ based on recoding of Malaysia and Singapore as indicated above. Empirical results in these two tables permit direct comparison of the impact of majoritarian democratic political institutions $(M A J)$ on growth with the impact of developmentally oriented autocracies $(D O A)$. Because the latter are known to have been responsible for these polities' high growth rates, this comparison allows one to ask, Has the shift from $D O A$ to $M A J$ resulted in a decline in growth rates? Table 4 tests the hypothesis that semidemocracies (SEMDEM) increase growth, as compared to $D O A$ s. Table 5 tests the hypothesis that the quality of democracy (POLITY2) increases growth as compared to DOAs.

Because it is likely that our democratic political variables of interest (MAJ, SEMDEM, and POLITY2) are endogenous to growth, TSLS panel regressions are estimated to control for endogeneity. As stated previously for $M A J$, first-stage regressions show the extra instruments are good instruments. First-stage regressions for SEMDEM and POLITY2 also similarly suggest that the extra instruments are good instruments. ${ }^{11}$ In addition, tests for overidentifying restrictions suggest that the extra instruments in each TSLS panel regression are not correlated with the error terms. ${ }^{12}$ 
Table 2 East Asian Growth Panel Regressions on Majoritarian Democracies (MAJ1) with Various Control Variables and with Panel Corrected Standard Errors (no degree of freedom correction)

\begin{tabular}{|c|c|c|c|c|c|c|}
\hline $\begin{array}{l}\text { Independent } \\
\text { Variables }\end{array}$ & OLS & TSLS & OLS & TSLS & OLS & TSLS \\
\hline $\mathrm{C}$ & 1.75 & 1.40 & -3.59 & -3.76 & -3.22 & -4.10 \\
\hline RELYNUS & & & $\begin{array}{l}-.02 \\
(-.83)\end{array}$ & $\begin{array}{c}-.02 \\
(-1.02)\end{array}$ & $\begin{array}{l}-.02 \\
(-.78)\end{array}$ & $\begin{array}{l}-.01 \\
(-.71)\end{array}$ \\
\hline KI & & & $\begin{array}{c}.19 \\
(6.13)^{* * *}\end{array}$ & $\begin{array}{c}.17 \\
(5.42)^{* * *}\end{array}$ & $\begin{array}{c}.19 \\
(5.87)^{* * *}\end{array}$ & $\begin{array}{c}.17 \\
(4.84)^{* * *}\end{array}$ \\
\hline POPG & & & $\begin{array}{c}.80 \\
(2.22)^{* *}\end{array}$ & $\begin{array}{c}.89 \\
(2.82)^{* * *}\end{array}$ & $\begin{array}{c}.80 \\
(2.20)^{* *}\end{array}$ & $\begin{array}{c}.88 \\
(2.84)^{* * *}\end{array}$ \\
\hline $\mathrm{KG}$ & & & & & $\begin{array}{l}-.01 \\
(-.16)\end{array}$ & $\begin{array}{l}.03 \\
(.35)\end{array}$ \\
\hline OPENK & & & & & $\begin{array}{l}.01 \\
(.62)\end{array}$ & $\begin{array}{c}.01 \\
(.73)\end{array}$ \\
\hline PIDEV & & & & & $\begin{array}{l}-.01 \\
(-.78)\end{array}$ & $\begin{array}{c}-.01 \\
(-1.02)\end{array}$ \\
\hline NDW & $\begin{array}{c}.01 \\
(.84)\end{array}$ & $\begin{array}{l}-.001 \\
(-.08)\end{array}$ & $\begin{array}{l}-.001 \\
(-.08)\end{array}$ & $\begin{array}{l}-.003 \\
(-.34)\end{array}$ & $\begin{array}{l}-.01 \\
(-.67)\end{array}$ & $\begin{array}{c}-.01 \\
(-1.07)\end{array}$ \\
\hline DOA1 & $\begin{array}{l}3.85 \\
(5.86)^{* * *}\end{array}$ & $\begin{array}{l}4.41 \\
(6.33)^{* * *}\end{array}$ & $\begin{array}{l}2.79 \\
(4.30)^{* * *}\end{array}$ & $\begin{array}{l}3.26 \\
(5.16)^{* * *}\end{array}$ & $\begin{array}{l}2.58 \\
(3.79)^{* * *}\end{array}$ & $\begin{array}{l}2.94 \\
(4.06)^{* * *}\end{array}$ \\
\hline MAJ1 & $\begin{array}{c}1.79 \\
(1.77)^{*}\end{array}$ & $\begin{array}{l}4.10 \\
(2.46)^{* * *}\end{array}$ & $\begin{array}{l}1.94 \\
(2.04)^{* *}\end{array}$ & $\begin{array}{l}3.76 \\
(2.67)^{* * *}\end{array}$ & $\begin{array}{l}1.89 \\
(2.00)^{* *}\end{array}$ & $\begin{array}{l}3.75 \\
(2.76)^{* * *}\end{array}$ \\
\hline $\operatorname{AR}(1)$ & $\begin{array}{c}.23 \\
(5.13)^{* * *}\end{array}$ & $\begin{array}{l}.11 \\
(.25)\end{array}$ & $\begin{array}{c}.20 \\
(4.58)^{* * *}\end{array}$ & $\begin{array}{l}-.01 \\
(-.01)\end{array}$ & $\begin{array}{c}.20 \\
(4.48)^{* * *}\end{array}$ & $\begin{array}{l}-.06 \\
(-.08)\end{array}$ \\
\hline $\begin{array}{l}\text { Number of } \\
\text { cross-sections }\end{array}$ & 11 & 11 & 11 & 11 & 11 & 11 \\
\hline$N$ & 547 & 547 & 547 & 547 & 547 & 547 \\
\hline $\begin{array}{l}\text { Equation F } \\
\text { J statistic }\end{array}$ & $9.02 * * *$ & .06 & $10.22 * * *$ & .03 & $8.72 * * *$ & .04 \\
\hline
\end{tabular}

Notes: Numbers in parentheses are $t$ values.

*Indicates statistically significant at the .10 level. ${ }^{* *}$ Indicates statistically significant at the .05 level. ${ }^{* * *}$ Indicates statistically significant at the .01 level. Following Reilly (2006), MAJI codes Malaysia and Singapore as majoritarian democracies.

So what did we find? Several results deserve mention. In Table 1, which compares the growth impact of $A U T$ and $D E M$, neither variable is ever statistically significant. Because a large theoretical, statistical, and case literature suggests that regime type probably does not affect growth, this result is not particularly surprising. ${ }^{13}$ Table 2 , which reports results for $M A J$ and $D O A$, shows that both variables have the correct sign and are statistically significant at the .01 or .05 level in all six equations. Moreover, Wald tests of the restriction that the regression coefficients (or growth effects) for $M A J$ are equal to 
Table 3 Robustness Check on East Asian Growth Panel Regressions for Majoritarian Democracy (MAJ2) with Various Control Variables and with Panel Corrected Standard Errors (no degree of freedom correction)

\begin{tabular}{|c|c|c|c|c|c|c|}
\hline $\begin{array}{l}\text { Independent } \\
\text { Variables }\end{array}$ & OLS & TSLS & OLS & TSLS & OLS & TSLS \\
\hline $\mathrm{C}$ & 1.50 & 1.24 & -3.57 & -3.73 & -2.92 & -3.73 \\
\hline RELYNUS & & & $\begin{array}{c}-.02 \\
(-1.05)\end{array}$ & $\begin{array}{c}-.02 \\
(-1.18)\end{array}$ & $\begin{array}{l}-.03 \\
(-.97)\end{array}$ & $\begin{array}{l}-.02 \\
(-.81)\end{array}$ \\
\hline KI & & & $\begin{array}{l}.19 \\
(5.91)^{* * *}\end{array}$ & $\begin{array}{c}.17 \\
(5.19)^{* * *}\end{array}$ & $\begin{array}{c}.19 \\
(5.56)^{* * *}\end{array}$ & $\begin{array}{c}.17 \\
(4.29)^{* * *}\end{array}$ \\
\hline POPG & & & $\begin{array}{c}.80 \\
(2.20)^{* *}\end{array}$ & $\begin{array}{c}.89 \\
(2.82)^{* * *}\end{array}$ & $\begin{array}{c}.80 \\
(2.20)^{* *}\end{array}$ & $\begin{array}{c}.88 \\
(2.79)^{* * *}\end{array}$ \\
\hline $\mathrm{KG}$ & & & & & $\begin{array}{l}-.04 \\
(-.36)\end{array}$ & $\begin{array}{c}.01 \\
(.10)\end{array}$ \\
\hline OPENK & & & & & $\begin{array}{l}.005 \\
(.51)\end{array}$ & $\begin{array}{l}.01 \\
(.52)\end{array}$ \\
\hline PIDEV & & & & & $\begin{array}{l}-.01 \\
(-.80)\end{array}$ & $\begin{array}{l}-.01 \\
(-.88)\end{array}$ \\
\hline NDW & $\begin{array}{l}.01 \\
(.72)\end{array}$ & $\begin{array}{l}-.002 \\
(-.20)\end{array}$ & $\begin{array}{l}-.001 \\
(-.09)\end{array}$ & $\begin{array}{l}-.004 \\
(-.34)\end{array}$ & $\begin{array}{l}-.01 \\
(-.80)\end{array}$ & $\begin{array}{l}-.01 \\
(-.89)\end{array}$ \\
\hline DOA2 & $\begin{array}{l}3.94 \\
(6.13)^{* * *}\end{array}$ & $\begin{array}{l}4.76 \\
(6.03)^{* * *}\end{array}$ & $\begin{array}{l}2.87 \\
(4.59)^{* * *}\end{array}$ & $\begin{array}{l}3.47 \\
(4.50)^{* * *}\end{array}$ & $\begin{array}{l}2.73 \\
(4.15)^{* * *}\end{array}$ & $\begin{array}{l}3.27 \\
(3.55)^{* * *}\end{array}$ \\
\hline MAJ2 & $\begin{array}{l}1.90 \\
(2.07)^{* *}\end{array}$ & $\begin{array}{l}4.46 \\
(2.60)^{* * *}\end{array}$ & $\begin{array}{l}2.22 \\
(2.56)^{* * *}\end{array}$ & $\begin{array}{l}3.94 \\
(2.52)^{* * *}\end{array}$ & $\begin{array}{l}2.13 \\
(2.48)^{* * *}\end{array}$ & $\begin{array}{l}3.94 \\
(2.52)^{* * *}\end{array}$ \\
\hline $\operatorname{AR}(1)$ & $\begin{array}{c}.23 \\
(5.07)^{* * *}\end{array}$ & $\begin{array}{l}.05 \\
(.10)\end{array}$ & $\begin{array}{c}.20 \\
(4.51)^{* * *}\end{array}$ & $\begin{array}{l}-.01 \\
(-.01)\end{array}$ & $\begin{array}{c}.20 \\
(4.43)^{* * *}\end{array}$ & $\begin{array}{l}-.01 \\
(-.02)\end{array}$ \\
\hline $\begin{array}{l}\text { Number of } \\
\text { cross-sections }\end{array}$ & 11 & 11 & 11 & 11 & 11 & 11 \\
\hline$N$ & 546 & 546 & 546 & 546 & 546 & 546 \\
\hline Equation $\mathrm{F}$ & $9.35^{* * *}$ & & $10.34 * * *$ & & $8.82 * * *$ & \\
\hline J statistic & & .02 & & .25 & & .23 \\
\hline
\end{tabular}

Notes: Numbers in parentheses are $t$ values.

*Indicates statistically significant at the .10 level. ${ }^{* *}$ Indicates statistically significant at the .05 level. ${ }^{* * *}$ Indicates statistically significant at the .01 level. $D O A 2$ recodes Malaysia and Singapore as developmental autocracies and not as majoritarian $(M A J 2)$ democracies.

those for $D O A$ are decisively not rejected. ${ }^{14}$ Said another way, after controlling for the other variables affecting growth, there is no significant difference in the growth impact between developmentally oriented autocratic governments and majoritarian democratic governments. In addition, the impacts of $D O A$ and $M A J$ on growth appear to be quite large-being a $D O A$ increases growth by an average of 3.30 percent, while being an $M A J$ increases growth by an average of 2.85 percent. 
Table 4 East Asian Growth Panel Regressions on Semidemocracy (SEMDEM) with Various Control Variables and with Panel Corrected Standard Errors (no degree of freedom correction)

\begin{tabular}{|c|c|c|c|c|c|c|}
\hline $\begin{array}{l}\text { Independent } \\
\text { Variables }\end{array}$ & OLS & TSLS & OLS & TSLS & OLS & TSLS \\
\hline $\mathrm{C}$ & 1.56 & 1.06 & -2.21 & -1.22 & -1.77 & .13 \\
\hline RELYNUS & & & $\begin{array}{c}-.04 \\
(-1.90)^{*}\end{array}$ & $\begin{array}{c}-.06 \\
(-1.26)\end{array}$ & $\begin{array}{c}-.05 \\
(-1.75)^{*}\end{array}$ & $\begin{array}{l}-.08 \\
(-.90)\end{array}$ \\
\hline KI & & & $\begin{array}{c}.18 \\
(5.78)^{* * *}\end{array}$ & $\begin{array}{c}.13 \\
(1.68)^{*}\end{array}$ & $\begin{array}{c}.17 \\
(5.45)^{* * *}\end{array}$ & $\begin{array}{c}.12 \\
(1.12)\end{array}$ \\
\hline POPG & & & $\begin{array}{c}.39 \\
(1.17)\end{array}$ & $\begin{array}{c}.08 \\
(.11)\end{array}$ & $\begin{array}{c}.40 \\
(1.20)\end{array}$ & $\begin{array}{l}.10 \\
(.13)\end{array}$ \\
\hline $\mathrm{KG}$ & & & & & $\begin{array}{l}-.04 \\
(-.37)\end{array}$ & $\begin{array}{l}-.10 \\
(-.35)\end{array}$ \\
\hline OPENK & & & & & $\begin{array}{l}.003 \\
(.30)\end{array}$ & $\begin{array}{l}-.001 \\
(-.04)\end{array}$ \\
\hline PIDEV & & & & & $\begin{array}{l}-.001 \\
(-.06)\end{array}$ & $\begin{array}{c}5.15 \mathrm{E}-05 \\
(.002)\end{array}$ \\
\hline NDW & $\begin{array}{c}.01 \\
(1.77)^{*}\end{array}$ & $\begin{array}{l}.01 \\
(.66)\end{array}$ & $\begin{array}{l}.01 \\
(.89)\end{array}$ & $\begin{array}{c}.01 \\
(1.19)\end{array}$ & $\begin{array}{c}.01 \\
(.54)\end{array}$ & $\begin{array}{c}.02 \\
(.62)\end{array}$ \\
\hline DOA1 & $\begin{array}{l}3.17 \\
(5.10)^{* * *}\end{array}$ & $\begin{array}{l}2.91 \\
(2.63)^{* * *}\end{array}$ & $\begin{array}{l}2.10 \\
(3.40)^{* * *}\end{array}$ & $\begin{array}{l}1.91 \\
(2.54)^{* * *}\end{array}$ & $\begin{array}{l}2.11 \\
(3.21)^{* * *}\end{array}$ & $\begin{array}{c}2.07 \\
(1.91)^{*}\end{array}$ \\
\hline SEMDEM & $\begin{array}{l}2.04 \\
(2.53)^{* * *}\end{array}$ & $\begin{array}{c}4.70 \\
(1.00)\end{array}$ & $\begin{array}{l}1.67 \\
(2.18)^{* *}\end{array}$ & $\begin{array}{c}4.17 \\
(1.39)\end{array}$ & $\begin{array}{l}1.67 \\
(2.17)^{* *}\end{array}$ & $\begin{array}{c}4.05 \\
(1.26)\end{array}$ \\
\hline $\operatorname{AR}(1)$ & $\begin{array}{c}.21 \\
(4.83)^{* * *}\end{array}$ & $\begin{array}{l}.50 \\
(.87)\end{array}$ & $\begin{array}{c}.19 \\
(4.27)^{* * *}\end{array}$ & $\begin{array}{l}.27 \\
(.29)\end{array}$ & $\begin{array}{c}.19 \\
(4.25)^{* * *}\end{array}$ & $\begin{array}{l}.33 \\
(.31)\end{array}$ \\
\hline $\begin{array}{l}\text { Number of } \\
\text { cross-sections }\end{array}$ & 11 & 11 & 11 & 11 & 11 & 11 \\
\hline $\begin{array}{l}N \\
\text { Equation } \mathrm{F}\end{array}$ & $\begin{array}{c}528 \\
8.94 * * *\end{array}$ & 528 & $\begin{array}{c}528 \\
9.91 * * *\end{array}$ & 528 & $\begin{array}{c}528 \\
8.39 * * *\end{array}$ & 528 \\
\hline J statistic & & .01 & & .09 & & .06 \\
\hline
\end{tabular}

Notes: Numbers in parentheses are $t$ values.

*Indicates statistically significant at the .10 level. ${ }^{* *}$ Indicates statistically significant at the .05 level. ***Indicates statistically significant at the .01 level.

The results in Table 3 using the more stringent definition of $M A J$ are basically identical to those in Table 2; regression coefficients on $D O A$ and $M A J$ are always positive and statistically significant at the .01 or .05 level. Wald tests of the restriction that the regression coefficients (or growth effects) for $M A J$ are equal to those for $D O A$ are decisively not rejected ${ }^{15}$ and the impacts of $D O A$ and $M A J$ are quite large-being a $D O A$ increases growth by 3.5 percent, while being an $M A J$ increases growth by 3.1 percent. One other fact about the results reported in Tables 2 and 3 deserves mention. The regression coefficient on the investment share in GDP $(K I)$ is always positive, statistically 
Table 5 East Asian Growth Panel Regressions on POLITY2 with Various Control Variables and with Panel Corrected Standard Errors (no degree of freedom correction)

\begin{tabular}{|c|c|c|c|c|c|c|}
\hline $\begin{array}{l}\text { Independent } \\
\text { Variables }\end{array}$ & OLS & TSLS & OLS & TSLS & OLS & TSLS \\
\hline $\mathrm{C}$ & 2.73 & 4.33 & -1.80 & .76 & -2.37 & -.65 \\
\hline RELYNUS & & & $\begin{array}{c}-.04 \\
(-1.69)^{*}\end{array}$ & $\begin{array}{c}-.06 \\
(-1.05)\end{array}$ & $\begin{array}{c}-.04 \\
(-1.43)\end{array}$ & $\begin{array}{l}-.06 \\
(-.87)\end{array}$ \\
\hline $\mathrm{KI}$ & & & $\begin{array}{l}.19 \\
(6.05)^{* * *}\end{array}$ & $\begin{array}{c}.14 \\
(1.61)\end{array}$ & $\begin{array}{c}.19 \\
(5.86)^{* * *}\end{array}$ & $\begin{array}{c}.14 \\
(1.53)\end{array}$ \\
\hline POPG & & & $\begin{array}{c}.60 \\
(1.75)^{*}\end{array}$ & $\begin{array}{l}.51 \\
(.80)\end{array}$ & $\begin{array}{c}.60 \\
(1.74)^{*}\end{array}$ & $\begin{array}{l}.53 \\
(.87)\end{array}$ \\
\hline $\mathrm{KG}$ & & & & & $\begin{array}{c}.04 \\
(.39)\end{array}$ & $\begin{array}{l}.08 \\
(.42)\end{array}$ \\
\hline OPENK & & & & & $\begin{array}{l}.01 \\
(.81)\end{array}$ & $\begin{array}{l}.01 \\
(.58)\end{array}$ \\
\hline PIDEV & & & & & $\begin{array}{l}-.001 \\
(-.03)\end{array}$ & $\begin{array}{l}.002 \\
(.12)\end{array}$ \\
\hline NDW & $\begin{array}{l}.01 \\
(.59)\end{array}$ & $\begin{array}{l}-.01 \\
(-.51)\end{array}$ & $\begin{array}{l}-4.83 \mathrm{E}-05 \\
(-.003)\end{array}$ & $\begin{array}{l}-.01 \\
(-.37)\end{array}$ & $\begin{array}{l}-.01 \\
(-.54)\end{array}$ & $\begin{array}{l}-.02 \\
(-.71)\end{array}$ \\
\hline DOA1 & $\begin{array}{l}3.90 \\
(5.54)^{* * *}\end{array}$ & $\begin{array}{l}5.21 \\
(2.81)^{* * *}\end{array}$ & $\begin{array}{l}2.83 \\
(4.16)^{* * *}\end{array}$ & $\begin{array}{c}4.16 \\
(1.71)^{*}\end{array}$ & $\begin{array}{l}2.78 \\
(3.91)^{* * *}\end{array}$ & $\begin{array}{c}4.01 \\
(1.59)\end{array}$ \\
\hline POLITY2 & $\begin{array}{c}.10 \\
(1.65)^{*}\end{array}$ & $\begin{array}{c}.36 \\
(1.16)\end{array}$ & $\begin{array}{c}.12 \\
(1.98)^{* *}\end{array}$ & $\begin{array}{c}.36 \\
(.92)\end{array}$ & $\begin{array}{c}.13 \\
(2.09)^{* *}\end{array}$ & $\begin{array}{l}.36 \\
(.98)\end{array}$ \\
\hline $\operatorname{AR}(1)$ & $\begin{array}{c}.23 \\
(5.08)^{* * *}\end{array}$ & $\begin{array}{l}.43 \\
(.90)\end{array}$ & $\begin{array}{c}.19 \\
(4.42)^{* * *}\end{array}$ & $\begin{array}{l}.46 \\
(.72)\end{array}$ & $\begin{array}{c}.19 \\
(4.29)^{* * *}\end{array}$ & $\begin{array}{l}.42 \\
(.59)\end{array}$ \\
\hline $\begin{array}{l}\text { Number of } \\
\text { cross-sections }\end{array}$ & 11 & 11 & 11 & 11 & 11 & 11 \\
\hline$N$ & 528 & 528 & 528 & 528 & 528 & 528 \\
\hline $\begin{array}{l}\text { Equation F } \\
\text { J statistic }\end{array}$ & $8.54 * * *$ & .02 & $9.81 * * *$ & .004 & $8.34 * * *$ & .002 \\
\hline
\end{tabular}

Notes: Numbers in parentheses are $t$ values.

*Indicates statistically significant at the .10 level. ${ }^{* *}$ Indicates statistically significant at the .05 level. ***Indicates statistically significant at the .01 level.

significant at the .01 level, very stable (between .17 and .19), and inherently reasonable. This is important simply because it is well known that growth in these economies has largely been driven by capital accumulation (Young 1995).

Table 4 reports results for the semidemocracy variable (SEMDEM), while Table 5 reports results for the quality of democracy variable (POLITY2). Both variables perform poorly. While the estimated coefficient on $S E M D E M$ is positive and statistically significant in all the ordinary least squares (OLS) equations, when controlled for endogeneity, the coefficients on SEMDEM become insignificant. The 
performance of the POLITY2 variable is no better. While it is positive and statistically significant in all of the OLS regressions, it is not significant in any of the TSLS regressions. Taken together, the findings reported in Tables 1 through 5 provide powerful support for the hypothesis that East Asia's majoritarian democracies are as growth enhancing as the region's developmental autocracies while neither pure democracy, semidemocracy, nor the quality of democracy has any impact on growth.

\section{Indonesian Case Study}

While these reduced form regression results are encouraging, they beg an important question: How precisely did the adoption of more majoritarian democratic political institutions in East Asia's new democracies affect the economic policies thought to affect growth? Even though there is, as yet, no definitive answer to this question, substantial leverage can be gained by using a case study of Indonesia, a country that transitioned from a developmental autocracy to a more majoritarian democracy, to identify the most likely causal mechanisms linking adoption of majoritarian institutions to growth-enhancing policies.

Indonesia's so-far successful democracy and development ${ }^{16}$ story begins with the collapse of the economy in 1998, which ignited widespread popular mobilization and substantial violence (Aspinwall 2005, 252). These events, alongside massive capital flight (Pepinsky 2009, 155 ) and the killing of middle-class university students by security forces, precipitated elite defection from and disintegration of the New Order (Webber 2006, 407). From the vantage point of 1998, Indonesia's democratic transition looked like a classic ruptura (Aspinwall 2005, 271) - a mode of transition considered unlikely to lead to a consolidation of democracy (Karl 1990, 8). Subsequently, old New Order elites captured the state and Indonesia's new democratic institutions, shifting emphasis during the post-transition period to pactmaking among the country's democratic elites, the military, and separatists (Aspinwall 2010). While Slater (2004), Webber (2006), and Hadiz (2003) have criticized the impact of pact-making on the quality of democracy, Aspinwall (2010) argues that concessions to the military and separatists alongside absorption of Islamist political forces into the democratic mainstream enabled Indonesia to consolidate democracy.

However, rapid collapse of the New Order and a shift to democratic pact-making are not sufficient to account for the ability of new democratic elites to consolidate democracy or put development back 
on track. Three other key developments-creating new, more majoritarian democratic institutions (Reilly 2006), building a more effective government by tackling corruption (Butt 2011), and restoring the institutions of macroeconomic policymaking to their previous place of prominence in government (Aswicahyono, Bird, and Hill 2009; Bird, Hill, and Culbertson 2008; Boediono 2005, 2002)-also mattered.

The turn toward majoritarianism occurred in fits and starts. To begin with, political elites rejected parliamentary democracy as inappropriate for Indonesia. ${ }^{17}$ At the same time, Indonesia adopted PR electoral rules, but with closed party lists to generate greater party cohesion (Slater 2004, 75). Indonesia also adopted large district magnitudes to ensure adequate representation of Indonesia's pluralist interests in its new democratic institutions (B. King 2004, 150) and it weakened the presidency (B. King 2004, 53-54, 76-77). The net effect of these new rules pushed the political system in a centrifugal direction (Liddle and Mujani 2006).

Subsequently, political elites reversed step by pushing the institutions of democracy in a decidedly centripetal direction. They used constitutional amendment to strengthen the presidency (B. King 2004, $54,151)$. In response to growing pressures for greater regional autonomy, Indonesia implemented big bang decentralization, but it did so in a way that protected its unitary state while constraining separatist movements. ${ }^{18}$ One important consequence of decentralization was an increase in the number of electoral districts. As electoral districts became smaller, district magnitudes fell, increasing majoritarian tendencies as winning seat thresholds rose from 5.7 percent of the votes in 1999 to 12.5 percent in 2004 and 13.7 percent in 2009 (Choi 2009, 673). Finally, the government adopted new rules for participation by political parties ${ }^{19}$ and candidates for president ${ }^{20}$ in national elections, which forced parties and presidential candidates to aggregate interests and compete for the political center. ${ }^{21}$

How successful has the move toward more majoritarian political institutions been? Reilly (2006) contends, and fragmentary evidence on democratic outcomes suggests, that democratic political institutions have moved in a majoritarian direction. As Mietzner (2008) shows, Indonesia's political parties have been competing for votes in the political center. While some of the shift to the center reflects the absence of a politically viable left (Mietzner 2008, 439), the moderate character of Indonesia's Islamic political parties (Aspinwall 2010, 29-31; Mietzner 2008, 447-452; Hefner 2000), and a keen interest in avoiding a repeat of the unstable democratic experience of the $1950 \mathrm{~s}$, at least some of the shift surely has something to do with the shift 
toward majoritarianism, which forced political parties to compete for votes by offering "cleaner" government and a return of growth. ${ }^{22}$ Voters have responded to these campaign promises by throwing out parties and leaders viewed as corrupt or unable to restore growth, ${ }^{23}$ and they have rewarded parties and political leaders who have delivered on one or both counts. ${ }^{24}$ This outcome creates incentives for political parties and elected presidents to rely more heavily on the country's economists and core macroeconomic institutions - the central bank, Ministry of Finance, and State Ministry of National Development Planning (BAPPENAS) - for counsel and advice.

Because political elites in Indonesia's democratic governments began competing for votes on the basis of cleaning up government and restoring growth, ${ }^{25}$ they have had to take steps to build a somewhat more effective government ${ }^{26}$ and restore the government's core macroeconomic institutions to their former positions of prominence. Indonesia's anticorruption commission has successfully prosecuted, and won, a significant number of highly visible anticorruption cases (Butt 2011, 381). ${ }^{27}$ This probably accounts for the substantial improvement in Indonesia's control of corruption score from 1 to 3.8 between 2005 and 2009, recorded by the Political Risk Services Group, following adoption of majoritarian institutions; it may also explain why there has not been much deterioration in the Political Risk Services Bureaucratic Quality score for Indonesia following adoption of more majoritarian democratic political institutions. ${ }^{28}$

Equally important, each of Indonesia's democratic governments sought the advice of its economists in core macroeconomic institutions. Given their highly successful role during the New Order this is not particularly surprising. But now, political elites, particularly presidents, turn to them in the hope they can help them stay in power by delivering development. There are numerous examples of this. In 1998, President Habibie relied on the advice of the country's economists in core macro agencies because he saw it as his best chance for succeeding as president (Boediono 2002, 388). Even during the phlegmatic Wahid administration, Indonesia's democratic government adhered to a traditional macroeconomic stabilization program (Boediono 2002, 390). And, as Boediono (2005, 315) says, during Megawati's presidency, the important economic portfolios were more insulated and the economic team was more cohesive and like-minded, allowing the government to establish macroeconomic stability. Subsequently, democratic governments created a "cordon sanitaire" around core macroeconomic institutions and principles via a law guaranteeing 
central bank independence and by stipulating in Fiscal Law 17/2003 that fiscal deficits be kept below 2 percent of GDP and the debt-toGDP ratio be kept lower than 60 percent (Aswicahyono, Bird, and Hill 2009, 357). As Aswicahyono, Bird, and Hill $(2009,357)$ conclude, overall Indonesia's macroeconomic policy framework under democracy has been quite effective.

However, this is not the only evidence that democratic governments relied on technocrats in the economic bureaucracy to restore growth. Following the collapse of the New Order, the short-lived Habibie government continued to support the International Monetary Fund's (IMF's) structural reform program because it was good politics (Bird, Hill, and Culbertson 2008, 958). While trade policy reform floundered under the Wahid and Megawati presidencies, following the election of Yudhoyono as president in October 2004, the government committed to tariffication of the remaining nontariff barriers (NTBs) and unification of tariffs at a rate of 5 percent by 2010 (Bird, Hill, and Culbertson 2008, 952). Responsibility for this stage of trade liberalization was given to an interministerial committee, Team Tariff, housed in a core macroeconomic agency, the Ministry of Finance. Through 2005 tariffication covered 1,900 items, mainly in agriculture, and 9,000 items through 2006 (Bird, Hill, and Culbertson 2008, 952). Although there has been some backsliding on trade policy reform, especially by the Ministry of Trade (Bird, Hill, and Culbertson 2008, 955-957), on the whole democratic governments in Indonesia, particularly after the emergence in 2005 of a more majoritarian democracy, have been able to sustain a trade liberalization program begun in the mid-1980s.

In sum, there is good reason to suspect that the shift in Indonesia toward a more majoritarian democratic political system played an important role in better control of corruption, especially compared to the 1998-2004 period, in the reemergence of sound macroeconomic policymaking, and in continuing support for trade liberalization, especially after 2004. First, democratically elected officials support these growth-enhancing policies because voters (Mujani and Liddle 2010, 42-44), even Islamic voters, expect governments to deliver development (Pepinsky, Liddle, and Mujani 2012, 10) ${ }^{29}$ In addition, it became possible for presidents and parties to focus on clean government and development partly because concessions to potential spoilers of democracy in the military removed the threat of military intervention in high politics. Candidate and political party focus on clean government and development was also facilitated by decentralization 
and concessions to potential separatists in Aceh and Papua, which substantially lessened the probability of political succession without undermining Indonesia's unitary state (Aspinwall 2011). But these policy and growth outcomes probably would not have been possible without the emergence of a more majoritarian party system ${ }^{30}$ that revolves around three major parties that compete for the political center and that have disarmed the Islamic parties forcing them to the center. ${ }^{31}$ Nor would this outcome have been likely without regular national campaigns for president and vice president that have driven candidates and their parties to the political center.

Said another way, the shift to more majoritarian democratic political institutions fostered a smaller number of centrist parties who competed for votes in the political center by committing themselves to the economic success of the entire country, rather than to more specific political or economic interests. More majoritarian institutions also forced candidates for the presidency and the vice presidency to do the same. At the same time, political elites took steps to create a more efficient government by controlling corruption, and they insulated a more efficient government from interest group pressures by creating a cordon sanitaire around key macroeconomic policies and restoring the government institutions responsible for macroeconomic stability and trade liberalization to their former positions of dominance. This enabled presidents to continue the practice, learned during the New Order, of relying on macroeconomic technocrats in core macroeconomic agencies to maintain both macroeconomic stability and trade reform.

\section{Conclusion}

What should one make of the arguments and findings reported here? There are several answers to this question. First, they confirm what a growing body of theoretical and empirical work demonstrates-when it comes to the impact of political institutions on growth, the devil really is in the details. Political regime type appears to be less important to growth than whether the micro institutions embedded in particular regime types encourage political elites to provide the public goods and policies deemed necessary for growth.

As is well known, a number of governments in East Asia relied on developmentally oriented authoritarian regimes to increase growth. But as is equally well known, authoritarian regimes outside East Asia have not been particularly good at stimulating economic growth. As the 
regional and country case literature on authoritarian regimes suggests, this difference in growth outcomes may well be due to the significant institutional differences among authoritarian regimes. At least in the East Asian newly industrializing economies, developmentally oriented authoritarian regimes built several enduring and growth-enhancing institutions - high-quality public sector bureaucracies (Evans and Rauch 1999) and a set of institutions that insulated those in them from politicians and popular pressures while also fostering development of embedded autonomy with the private sector (Evans 1995; Johnson 1987). Nothing like this particular political formation has appeared in sub-Saharan Africa, a region that, until recently, has been characterized by a large number of authoritarian regimes. There the micro institutions of autocracy were used to buttress neopatrimonial ties been patrons and clients that were good at providing patronage, but poor at providing the public goods or policies necessary for growth (Van de Walle 2001).

Something similar appears to be at work within democratic political institutions in East Asia. As Reilly (2006) has argued, democratic governments in the East Asian newly industrializing economies have constructed a particular set of democratic institutions-mixedmember majoritarian electoral systems, cross-ethnic vote-pooling political coalitions (Horowitz 2000, 1989), party systems that are less fragmented and polarized than elsewhere, and more stable executive government - that encourage politicians to appeal to broad groups of the electorate by providing the public goods and policies necessary for growth. As a result, the political shift from developmental autocracy to majoritarian democracy in these polities has occurred without a significant slowdown in economic growth. Reilly (2006) argues that this particular political architecture is unique within the developing world. If he is right, it just might be that political elites elsewhere, who opted for a more consociational set of political institutions following democratization, may have unwittingly made it more difficult for governing elites in those polities to provide both the public goods and the policies necessary to get growth going.

Michael T. Rock is the Samuel and Etta Wexler Professor of Economic History at the Department of Economics, Bryn Mawr College. He is author (with David Angel) of Industrial Transformation in the Developing World (2005) and Pollution Control in East Asia (2002). His work has appeared in World Development, Studies in Comparative International Development, the Journal of Development Studies, the Bulletin of Indonesian Economic Studies, the Journal of Industrial Ecology, the Journal of International Development, and Ecological Economics. 
Appendix Table 1 Data, Definitions, and Sources

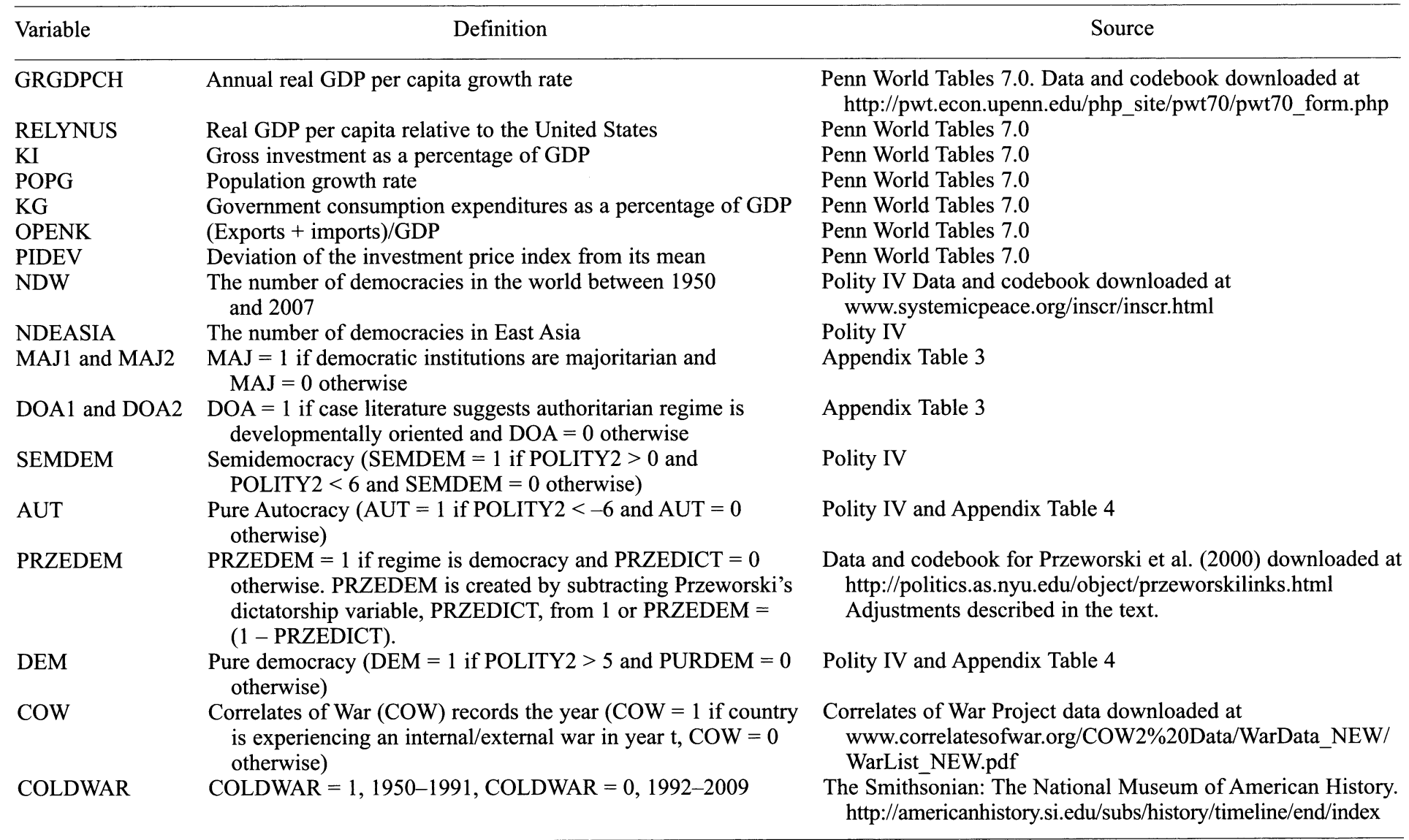


Appendix Table 2 Descriptive Statistics

\begin{tabular}{lrrrr}
\hline Variable & Mean & $\begin{array}{c}\text { Standard } \\
\text { Deviation }\end{array}$ & Minimum & Maximum \\
\hline GRGDPCH & 4.19 & 5.02 & -19.84 & 23.92 \\
RELYNUS & 17.31 & 21.48 & 1.86 & 115.42 \\
KI & 25.36 & 11.51 & 5.38 & 54.75 \\
POPG & 2.04 & .99 & -3.52 & 5.74 \\
KG & 10.18 & 5.11 & 2.61 & 29.78 \\
OPENK & 83.78 & 83.70 & 3.45 & 443.08 \\
PIDEV & -7.03 & 25.60 & -57.66 & 84.10 \\
NDEASIA & 3.65 & 2.08 & 1 & 7 \\
NDW & 61.60 & 26.38 & 34 & 110 \\
MAJ1 & .24 & .43 & 0 & 1 \\
MAJ2 & .18 & .39 & 0 & 1 \\
DOA1 & .30 & .45 & 0 & 1 \\
DOA2 & .38 & .48 & 0 & 1 \\
SEMDEM & .16 & .37 & 0 & 1 \\
DEM & .18 & .38 & 0 & 1 \\
PRZEDEM & .20 & .40 & 0 & 1 \\
AUT & .43 & .49 & 0 & 1 \\
COW & .19 & 1.52 & 0 & 1 \\
COLDWAR & .64 & .48 & 0 & 1 \\
\hline
\end{tabular}




\section{Appendix Table 3 Coding of Country Years for DOA and MAJ}

\begin{tabular}{|c|c|c|c|c|}
\hline Country & Coding for DOA & Source & Coding for MAJ & Source \\
\hline Cambodia & DOA1 always 0 & No literature indicating a DOA & $\begin{array}{l}\text { MAJ1 = 0, 1953-1997; } \\
\text { MAJ1 = 1, 1998-2009 }\end{array}$ & $\begin{array}{l}\text { Reilly (2006), Albritton (2004), Gallup } \\
\text { (2002), Hughes (2009) }\end{array}$ \\
\hline China & $\begin{array}{l}\text { DOA1 }=0,1950-1977 \\
\text { DOA1 }=1,1978-2009\end{array}$ & $\begin{array}{l}\text { Naughton (2007), Brandt and } \\
\text { Rawski (2008) }\end{array}$ & MAJ1 always 0 & China is never democratic (Polity IV) \\
\hline Indonesia & $\begin{array}{l}\text { DOA1 }=0,1950-1965 \\
\text { DOA1 }=1,1966-1997\end{array}$ & $\begin{array}{l}\text { Hill (1996), Liddle (1991), } \\
\text { Rock }(2003,1999)\end{array}$ & $\begin{array}{l}\text { MAJ1 }=0,1950-2004 \\
\text { MAJ1 }=1,2005-2009\end{array}$ & $\begin{array}{l}\text { Reilly (2006), Tan (2002), Ellis (2000), } \\
\quad \text { Sulistyo (2002) }\end{array}$ \\
\hline South Korea & $\begin{array}{l}\text { DOA } 1=0,1950-1960 \\
1987-2009 \\
\text { DOA } 1=1,1961-1987\end{array}$ & $\begin{array}{l}\text { Woo (1991), Haggard and } \\
\text { Moon (1990), Haggard } \\
\text { (1990), Amsden (1989), } \\
\text { Johnson (1987) }\end{array}$ & $\begin{array}{l}\text { MAJ1 }=0,1950-1987 \\
\text { MAJ1 }=1,1987-2009\end{array}$ & $\begin{array}{l}\text { Im (2004), Reilly (2006), Croissant (2002, } \\
\text { 2001), Brady and Mo (1992) }\end{array}$ \\
\hline Laos & DOA1 always 0 & No literature indicating a DOA & MAJ1 always 0 & Laos is never democratic (Polity IV) \\
\hline Malaysia & $\begin{array}{l}\text { DOA1 always } 0 \text { from } \\
\text { independence in } 1957 \\
\text { DOA2 }=1,1971-2003 \\
\text { DOA2 }=01957-1970 \\
2004-2009\end{array}$ & $\begin{array}{l}\text { Jomo }(2007,2001,1986) \\
\text { Rock and Sheridan }(2007), \\
\text { Khoo }(2003,1995)\end{array}$ & $\begin{array}{l}\text { MAJ1 always }=1 \\
\text { MAJ2 }=1,1957-1970 \\
2004-2009 \\
\text { MAJ2 }=0,1971-2003\end{array}$ & $\begin{array}{l}\text { Reilly (2006), Lim (2002), Horowitz (2000, } \\
\text { 1989) }\end{array}$ \\
\hline Philippines & DOA1 always 0 & Hutchcroft $(2000,1998,1991)$ & $\begin{array}{l}\text { MAJ1 }=1,1950-1971 \\
\text { MAJ1 }=0,1972-1985 \\
\text { MAJ1 }=1,1986-2009\end{array}$ & $\begin{array}{l}\text { Reilly (2006), Hutchcroft and Racamora } \\
\text { (2003), Hartmann, Hassall, and Santos } \\
\text { (2001), Teehankee (2002), Choi (2001), } \\
\text { Shugart and Carey (1992), Montinola } \\
\text { (1999) }\end{array}$ \\
\hline
\end{tabular}




\section{Appendix Table 3 Continued}

\begin{tabular}{|c|c|c|c|c|}
\hline Country & Coding for DOA & Source & Coding for MAJ & Source \\
\hline Singapore & $\begin{array}{l}\text { DOA1 always } 0 \\
\text { DOA2 }=1,1965-2009\end{array}$ & Huff (1997), Haggard (1990) & $\begin{array}{l}\text { MAJ1 always } 1, \\
\text { MAJ2 }=1 \text { prior to } \\
1965, \text { MAJ2 }=0 \\
1965-2009\end{array}$ & $\begin{array}{l}\text { Reilly (2006), Rieger (2001), Yeo (2002), } \\
\text { Mutalib (2002), Ganesan (1996) }\end{array}$ \\
\hline Taiwan & $\begin{array}{l}\text { DOA } 1=0,1950-1959 \\
\text { DOA } 1=1,1960-1991 \\
\text { DOA } 1=0,1992-2009\end{array}$ & Wade (1990), Haggard (1990) & $\begin{array}{l}\text { MAJ1 }=0,1950-2004 \\
\text { MAJ1 }=1,2004-2009\end{array}$ & Reilly (2006), Lin (2006), Rinza (2001) \\
\hline Thailand & $\begin{array}{l}\text { DOA } 1=0,1950-1959 \\
\text { DOA } 1=1,1960-1988 \\
\text { DOA1 }=0,1989-2009\end{array}$ & $\begin{array}{l}\text { Doner (2009), Thak (2007), } \\
\text { Rock (2000, 1995, 1994), } \\
\text { Muscat (1994), Laothamatas } \\
\text { (1997) }\end{array}$ & $\begin{array}{l}\text { MAJ1 }=0,1950-1997 \\
2006-2009 \\
\text { MAJ1 }=1,1998-2005\end{array}$ & $\begin{array}{l}\text { Hicken and Selway (2011), Hicken (2009), } \\
\text { Reilly (2006), Kopol (2002), Chamber } \\
\text { (2008), D. King (1996), McCargo (1997) }\end{array}$ \\
\hline Vietnam & $\begin{array}{l}\text { DOA1 }=0,1976-1985 \\
\text { DOA1 }=1,1986-2009\end{array}$ & $\begin{array}{l}\text { Thoburn (2009), Chaponniere } \\
\text { et al. (2008), Ljunggren } \\
\text { (1993) }\end{array}$ & MAJ1 always 0 & Vietnam never a democracy (Polity IV) \\
\hline
\end{tabular}




\begin{tabular}{|c|c|c|c|}
\hline Country & Coding for PURAUT & Coding for PURDEM & Coding for SEMDEM \\
\hline Cambodia & $\begin{array}{l}\text { AUT }=1,1954-1971, \\
1976-1978,1997 \\
\text { AUT }=0,1972-1975 \\
1988-1996 \\
1998-2009\end{array}$ & $\begin{array}{l}\text { DEM }=0,1953-1978 \\
1988-2009\end{array}$ & $\begin{array}{l}\text { SEMDEM = 1, 1990-1996, } \\
1998-2009 \\
\text { SEMDEM = 0, 1953-1978, } \\
1988-1989,1997\end{array}$ \\
\hline China & $\mathrm{AUT}=1,1950-2009$ & $\mathrm{DEM}=0,1950-2009$ & SEMDEM $=0,1950-2009$ \\
\hline Indonesia & $\begin{aligned} \text { AUT } & =1,1966-1997 \\
\text { AUT } & =0,1950-1965 \\
1998-2009 & \end{aligned}$ & $\begin{array}{l}\mathrm{DEM}=0,1950-1998 \\
\mathrm{DEM}=1,1999-2009\end{array}$ & SEMDEM $=0,1950-2009$ \\
\hline South Korea & $\begin{array}{l}\text { AUT }=1,1961-1962 \\
\quad 1972-1980 \\
\text { AUT }=0,1950-1960 \\
1963-1971 \\
1981-2009\end{array}$ & $\begin{array}{l}\mathrm{DEM}=1,1960 \\
1988-2009 \\
\mathrm{DEM}=0,1950-1959, \\
1961-1987\end{array}$ & $\begin{array}{l}\text { SEMDEM = 1, 1963-1971, } \\
1987 \\
\text { SEMDEM = 0, 1950-1962, } \\
1988-2009\end{array}$ \\
\hline Laos & $\begin{array}{l}\text { AUT }=1,1975-2009 \\
\text { AUT }=0,1954-1974\end{array}$ & $\begin{array}{c}\mathrm{DEM}=1,1957-1959 \\
\mathrm{DEM}=0,1954- \\
1956,1960-2009\end{array}$ & $\begin{array}{l}\text { SEMDEM }=1,1955-1956, \\
\text { SEMDEM }=0,1954, \\
1957-2009\end{array}$ \\
\hline Malaysia & AUT $=0,1957-2009$ & $\begin{array}{l}\mathrm{DEM}=1,1957-1968 \\
2008-2009 \\
\mathrm{DEM}=0,1969-2007\end{array}$ & $\begin{array}{l}\text { SEMDEM }=1,1969-2007 \\
\text { SEMDEM }=0,1957-1968, \\
\quad 2008-2009\end{array}$ \\
\hline Philippines & $\begin{array}{l}\text { AUT }=1,1972-1985 \\
\text { AUT }=0,1950-1971 \\
\quad 1986-2009\end{array}$ & $\begin{array}{l}\mathrm{DEM}=1,1987-2009 \\
\mathrm{DEM}=0,1950-1986\end{array}$ & $\begin{array}{l}\text { SEMDEM }=1,1950-1971, \\
1986 \\
\text { SEMDEM }=0,1972-1985, \\
1987-2009\end{array}$ \\
\hline Singapore & $\begin{array}{l}\text { AUT }=0,1959-1962 \\
1965-2009\end{array}$ & $\begin{array}{l}\mathrm{DEM}=1,1959-1962 \\
\mathrm{DEM}=0,1965-2009\end{array}$ & $\begin{array}{l}\text { SEMDEM }=1,1965- \\
\text { 2009, SEMDEM =0, } \\
\text { 1959-1962 }\end{array}$ \\
\hline Taiwan & $\begin{array}{l}\text { AUT }=1,1950-1986 \\
\text { AUT }=0,1987-2009\end{array}$ & $\begin{array}{l}\mathrm{DEM}=1,1992-2009 \\
\mathrm{DEM}=0,1950-1991\end{array}$ & SEMDEM = 0, 1950-2009 \\
\hline Thailand & $\begin{array}{l}\text { AUT }=1,1952-1954 \\
1958-1967, \\
1971-1972,1976 \\
\text { AUT }=0,1950- \\
1951,1955-1957 \\
1968-1970,1973- \\
1975,1977-2009\end{array}$ & $\begin{array}{l}\mathrm{DEM}=1,1992-2005 \\
\mathrm{DEM}=0,1950-1991 \\
\quad 2006-2009\end{array}$ & $\begin{array}{l}\text { SEMDEM = 1, 1969-1970, } \\
\text { 1974-1975, 1978-1990, } \\
2008-2009 \\
\text { SEMDEM =0, 1950-1968, } \\
\text { 1971-1973, 1976-1977, } \\
1991-2007\end{array}$ \\
\hline Vietnam & AUT $=1,1976-2009$ & $\mathrm{DEM}=0,1976-2009$ & SEMDEM = 0, 1976-2009 \\
\hline
\end{tabular}

Source: Polity IV (2010).

Notes: $A U T=1$ if POLITY2 $<-5, A U T=0$ if POLITY2 $>-6 . D E M=1$ if POLITY2 $>5$, DEM $=0$ if POLITY2 $<6$. SEMDEM $=1$ if POLITY2 $>0$ and POLITY2 $<6$. SEMDEM $=0$ if POLITY2 $<1 . S E M D E M=1$ for Singapore 1965-2009; otherwise $S E M D E M=0$. 


\section{Notes}

I would like to thank Marc Ross, Ben Reilly, the anonymous reviewers, and the editor of JEAS, Stephan Haggard, for helpful comments on earlier drafts. Any remaining errors are, of course, mine.

1. Additional cross-country evidence is in Hicken (2009), Hicken and Kasuya (2003), Hicken and Kuhonta (2011), Nohlen, Bruns, and John (2002), and Nohlen, Grotz, and Hartmann (2001). Case evidence appears in Appendix Table 3.

2. They also demonstrate that parliamentary regimes extract higher rents and higher taxes than presidential regimes (Persson and Tabellini 2005, 23-24).

3. As described below, both the majoritarian democracy variable (MAJ) and the developmental autocracy variable $(D O A)$ used in the difference-indifference fixed country effects panel regressions are dummy variables. $M A J$ $=1$ for each country year of majoritarian democracy and $M A J=0$ otherwise. $D O A=1$ for each country year of developmental autocracy and $D O A=0$ otherwise.

4. The control group includes country years for both nondevelopmental autocracies, such as Laos between 1973 and 2009 and the Philippines between 1972 and 1985, and nonmajoritarian democracies, such as Taiwan between 1992 and 2004.

5. The justification for these instruments is as follows: Given the historical preference among East Asia's democracies for majoritarian institutions, as the number of democracies rises a majoritarian diffusion effect may be at work. Lagged values of Przeworski's democracy variable should exert a similar diffusion effect. Finally, since the polities of East Asia have suffered a significant number of internal wars largely in multiethnic environments, political elites may have opted for majoritarian institutions as one way to defang separatist tendencies.

6. In the first-stage regression on $M A J$, the hypothesis that the regression coefficient on the extra instrumental variables is equal to zero is decisively rejected (the $F$ value for this restriction $=52.25$ ). This suggests, following Staiger and Stock (1997), that these instruments are good instruments.

7. Data availability depends on country year of independence (as in 1957 for Malaysia) or country year of reuniting of a country (as 1976 for Vietnam) and data availability for either political institutions or economic variables. The latter is affected by the degree of political instability within a polity, particularly for Cambodia (prior to 1970 and between 1979 and 1987) and Laos (prior to 1970), Indonesia (between 1950 and 1960), and Korea during the Korean War (1950-1953).

8. I also wanted to test for the effect of consociational or consensus democracy on growth but there were very few country years that fell in this category and, to make matters worse, one reviewer of an earlier version of this paper strongly objected to my categorizations of country years as consociational democracies. As a result, I reluctantly dropped consideration of consociational democracies from the analysis. 
9. For example, $D O A=1$ in Indonesia for the years of Suharto's developmentally oriented authoritarian New Order government.

10. As Table 3 shows, both $M A J$ and $D O A$ vary over time, sometimes quite dramatically, especially for those countries that started out as developmental autocracies and ended up as majoritarian democracies.

11. SEMDEM is instrumented by $C O W$, lagged values of a POLITY2 autocracy dummy variable ( $A U T)$, and a dummy variable for the Cold War (COLDWAR). In the first-stage regression for SEMDEM, the hypothesis that the regression coefficients on the extra instrumental variables are equal to zero is decisively rejected $(\mathrm{F}=41.93)$. POLITY2 is instrumented by the number of democracies in East Asia (NDEASIA), a dummy variable for the Cold War (COLDWAR), and lagged values of Przeworski's democracy variable (PRZEDEM). In the first-stage regression for POLITY2, the hypothesis that the regression coefficient on the extra instrumental variables is equal to zero is decisively rejected $(F=72.24)$. This suggests, following Staiger and Stock (1997), that these instruments are good instruments.

12. See J statistic for each TSLS regression in Tables 1-5.

13. A good summary of this literature can be found in Papaioannou and Siourounis (2008).

14. The $\mathrm{F}$ statistics for this restriction for each equation in Table 2 are $\mathrm{F}$ $=2.08, \mathrm{~F}=.22, \mathrm{~F}=.77, \mathrm{~F}=.18, \mathrm{~F}=.47$, and $\mathrm{F}=.48$. Except for the $\mathrm{F}$ value for the first OLS panel regression, none of the other F values is statistically significant.

15. The $F$ statistics for this restriction for each equation in Table 3 are $F$ $=5.80, \mathrm{~F}=.06, \mathrm{~F}=.61, \mathrm{~F}=.18, \mathrm{~F}=.47$, and $\mathrm{F}=.36$. Except for the $\mathrm{F}$ value for the first OLS panel regression, none of the other $F$ values is statistically significant.

16. I say successful development because the annual growth rate of real GDP per capita since democratization (3.58 percent) is not significantly different than it was during the New Order (4.24 percent [World Bank 2012]). A simple difference of means test fails to reject the null hypothesis that there is no difference in growth rates $(t=-.54)$.

17. Party leaders rejected pure parliamentary democracy because they associated it with the instability of governments between 1950 and 1959 (B. King 2004, 143).

18. Decentralization bypassed provinces and focused on local governments to minimize secessionist threats and enable the central government to maintain more control through a "divide and rule" strategy (Fitrani, Hofman, and Kaiser 2005, 61).

19. Political parties that ran for election in 1999 could only run in 2004 if they held 2 percent of the seats in the People's Representative Council (DPR) or 3 percent of the seats in the Regional People's Representative Council (DPRD) in one-half of the provinces or 3 percent of the DPRD seats in one-half of Indonesia's regencies (Choi 2009, 679). In addition, parties had to have executive committees in two-thirds of the provinces, two-thirds of the regencies, and they had to have at least 1,000 party members in both 
or $1 / 1000$ of the population as party members in regencies, raising the entry barrier for new parties (Choi 2009, 680).

20 . To run a candidate for president in 2004 , parties had to have garnered either 5 percent of the vote in the 1999 DPR election or 3 percent of the seats (Choi 2009, 681). For the 2009 presidential election, parties had to have captured at least 25 percent of the popular vote and 20 percent of the seats in the DPR (Choi 2009, 682).

21 . These rules increased disproportionality in the assignment of votes to seats from 1.54 in 1955 to 4.45 in 2004 and 6.84 in 2008 , and they reduced the effective number of parties in parliament from 7.07 in 2004 to 6.13 in 2009 (www.tcd.ie/Political_Science/staff/michael_gallagher/El Systems/).

22. In 2004 Yudhoyono campaigned on a promise to achieve a 6 percent GDP growth rate (Liddle and Mujani 2006, 137) and he delivered on it as real GDP grew by 5.9 percent during his first term (World Bank 2012). He also promised to clean up corruption, which he did as Indonesia's score on the Control of Corruption Index of the Political Risk Service rose from a low of 1 throughout Megawati's presidency to 3.58 by the end of Yudhoyono's first term (Political Risk Services 2012).

23. All of the large major parties lost votes between 1999 and 2009 elections, but the losses were greatest for PKB ( 51 percent), Golkar (45 percent), and PDI-P (39 percent) (Choi 2009, 678). Public opinion polls show parties are not trusted by voters (Tan 2002, 104) and the poor economic (real GDP grew at 4.5 percent [World Bank 2012]) and anticorruption performance of Megawati probably cost her votes as she lost to Yudhoyono 61 percent to 39 percent in 2004 (Liddle and Mijani 2006, 133).

24. During Yudhoyono's first term his most popular initiative was the launching of an aggressive anticorruption campaign that netted a number of high-profile arrests (Mietzner 2009, 149-150). Not surprisingly, in 2009 Yudhoyono's Partai Demokrat captured 148 seats (26.4 percent of the seats) to become the largest party in parliament and Yudhoyono won reelection with 60.8 percent of the popular vote (Mietzner 2010, 188).

25. As Pepinsky, Liddle, and Mujani $(2012,14)$ say, even the "Islamic parties must establish favorable economic policy credentials to have any hope of attracting . . . mass support. . . Both party types . . . have internalized these ideas, as all parties portray themselves as faithful stewards of the Indonesian economy."

26. Improvement on this score, particularly in reining in corruption, has been limited to Yudhoyono's presidency (Mietzner 2009).

27. That said, there is growing evidence of efforts to undermine Indonesia's Anti-Corruption Court (Butt 2011, 381-382).

28. Indonesia's score on the Bureaucratic Quality Index declined during Megawati's presidency but has been holding steady during Yudhoyono's presidency (www.prsgroup.com/ICRG.aspx).

29. The Islamic parties have also accepted their defeat in the constitutional debate and have suspended demands for an Islamic state (Mietzner 
2008, 452). They have reached out to non-Muslims (Aspinwall 2010, 29) and they have been tarred with corruption and patronage as a consequence of their role in governing (Aspinwall 2010, 31).

30. While Indonesia's centripetal party system has been fostered by vote thresholds and geographic requirements, it may also have been accidentally nudged along by declining district magnitudes following decentralization. As noted earlier, decentralization led to a rapid increase in the number of electoral districts and an equally rapid decline in district magnitude from a mean of 17.5 in 1999 to 8 in 2004 and 7.3 in 2009 (Choi 2009, 672).

31. The Islamic parties have also been forced to the center by declining vote shares (Aspinwall 2010, 29). Moreover, among Indonesia's Islamic parties, economic platforms now dominate (Pepinsky, Liddle, and Mujani 2012, 10).

\section{References}

Albritton, Robert B. 2004. "Cambodia in 2003: On the Road to Democratic Consolidation." Asian Survey 44, 1: 102-109.

Amsden, Alice. 1989. Asia's Next Giant. New York: Oxford University Press.

Aspinwall, Edward. 2005. Opposing Suharto: Compromise, Resistance and Regime Change in Indonesia. Stanford: Stanford University Press. 2010. "The Irony of Success." Journal of Democracy 21, 2: 20-34. . 2011. "Democratization and Ethnic Politics in Indonesia." Journal of East Asian Studies 11: 289-319.

Aswicahyono, Haryo, Kelly Bird, and Hall Hill. 2009. "Making Economic Policy in Weak, Democratic, Post-crisis States: An Indonesian Case Study." World Development 37, 2: 354-370.

Barro, Robert. 1991. "Economic Growth in a Cross-section of Countries." Quarterly Journal of Economics 106: 407-443.

Beck, Nathaniel, and Jonathan N. Katz. 1995. "What to Do (and Not to Do) with Time Series Cross-section Data." American Political Science Review 89, 3: 634-647.

Besley, Timothy, and Anne Case. 2000. "Unnatural Experiments? Estimating the Incidence of Endogenous Policies." The Economic Journal 110, 467: F672-F694.

Bird, Kelly, Hall Hill, and Sandy Culbertson. 2008. "Making Trade Policy in a New Democracy After a Deep Crisis: Indonesia." The World Economy 31, 7: 947-968.

Boediono. 2002. "The IMF Support Program: Comparing Implementation Under Three Presidents." Bulletin of Indonesian Economic Studies 38, 3: 385-391.

- 2005. "Managing the Indonesian Economy: Some Lessons from the Past." Bulletin of Indonesian Economic Studies 41, 3: 309-324.

Brady, David, and Jongryn Mo. 1992. "Electoral Systems and Institutional Choice: A Case Study of the 1988 Korean Elections." Comparative Political Studies 24, 4: 405-429. 
Brandt, Loren, and Thomas G. Rawski, eds. 2008. China's Great Economic Transformation. Cambridge: Cambridge University Press.

Butt, Simon. 2011. "Anti-corruption Reform in Indonesia: An Obituary?" Bulletin of Indonesian Studies 47, 3: 381-394.

Callahan, William A., and Duncan McCargo. 1996. "Vote-buying in Thailand's Northeast." Asian Survey 36, 4: 376-391.

Case, William. 2002. Politics in Southeast Asia: Democracy or Less. London: Routledge.

Chamber, Paul. 2008. "Factions, Parties and the Durability of Parliaments, Coalitions and Cabinets." Party Politics 14, 3: 299-323.

Chaponniere, Jean-Raphael, Jean-Pierre Cling, and Bin Zhou. 2008. "Vietnam Following in China's Footsteps: The Third Wave of Emerging Asian Economies." UNU-WIDER Research Paper, no. 84. Helsinki, Finland.

Choi, Jungug. 2001. "Philippine Democracies Old and New: Elections, Term Limits and Party Systems." Asian Survey 41, 3: 488-501.

- 2009. "District Magnitude, Social Diversity and Indonesia's Parliamentary Party System from 1999 to 2009." Asian Survey 50, 4: 663-683.

Croissant, Aurel. 2001. "Korea (Republic of Korea/South Korea)." In Elections in Asia and the Pacific: A Data Handbook, ed. Dieter Nohlen, Florian Grotz, and Christof Hartmann, 411-479. Oxford: Oxford University Press.

- 2002. "Electoral Politics in South Korea." In Electoral Politics in Southeast and East Asia, ed. Dieter Nohlen, Gabriele Bruns, and Marei John, 233-276. Singapore: Friedrich Ebert Stiftung.

Doner, Richard. 2009. The Politics of Uneven Development: Thailand's Economic Growth in Comparative Perspective. Cambridge: Cambridge University Press.

Ellis, Andrew. 2000. "The Politics of Electoral Systems in Transition: The 1999 Elections in Indonesia and Beyond." Representation 37: 241-248.

Evans, Peter. 1995. Embedded Autonomy: States and Industrial Transformation. Princeton: Princeton University Press.

Evans, P., and J. E. Rauch. 1999. "Bureaucracy and Growth: A Cross National Analysis of the Effects of Weberian State Structures on Economic Growth." American Sociological Review 64, 5: 748-765.

Fitrani, Fitria, Bert Hofman, and Kal Kaiser. 2005. "Unity in Diversity: The Creation of New Local Governments in a Decentralizing Indonesia." Bulletin of Indonesian Economic Studies 41, 1: 57-79.

Gallup, Jeffrey. 2002. "Cambodia's Electoral System: A Window of Opportunity for Reform." In Electoral Politics in Southeast and East Asia, ed. Dieter Nohlen, Gabriele Bruns, and Marei John, 25-73. Singapore: Friedrich Ebert Stiftung.

Ganesan, Narayanan. 1996. "Democracy in Singapore." Asian Journal of Political Science 4, 2: 63-79.

Hadiz, Vedi R. 2003. "Re-organizing Political Power in Indonesia: A Reconsideration of So-called Democratic Transitions." The Pacific Review 16, 4: 591-611. 
Haggard, Stephan. 1990. Pathways from the Periphery. Ithaca: Cornell University Press.

Haggard, Stephan, and Robert R. Kaufmann. 1995. The Political Economy of Democratic Transitions. Princeton: Princeton University Press.

Haggard, Stephan, and Chung-in Moon. 1990. "Institutions and Economic Policy: Theory and a Korean Case Study." World Politics 42, 2: 210-237.

Hartmann, Christof, Graham Hassall, and Soliman M. Santos Jr. 2002. "Philippines." In Electoral Politics in Southeast and East Asia, ed. Dieter Nohlen, Gabriele Bruns, and Marei John, 185-238. Singapore: Friedrich Ebert Stiftung.

Hefner, Robert W. 2000. Civil Islam. Princeton: Princeton University Press.

Hicken, Allen. 2006. "Party Fabrication: Constitutional Reform and the Rise of Thai Rak Thai." Journal of East Asian Studies 6, 3: 381-407.

2009. Building Party Systems in Developing Democracies. Cambridge: Cambridge University Press.

Hicken, Allen, and Yuko Kasuya. 2003. "A Guide to the Constitutional Structures and Electoral Systems in East, South and Southeast Asia." Electoral Studies 22: 121-151.

Hicken, Allen, and Erik Kuhonta. 2011. "Shadows from the Past: Party System Institutionalization in Asia." Comparative Political Studies 44, 5: 572-597.

Hicken, Allen, and Joel S. Selway. 2011. "Forcing the Genie Back in the Bottle: Sociological Considerations of Institutional Reform in Thailand Through the Window of Health Policy." World Politics 63, 1: 165-202.

Hill, Hall. 1996. The Indonesian Economy. Cambridge: Cambridge University Press.

Horowitz, Donald L. 1989. "Incentives and Behavior in the Ethnic Politics of Sri Lanka and Malaysia." Third World Quarterly 11, 4: 18-35.

- 2000. Ethnic Groups in Conflict. 2nd ed. Berkeley: University of California Press.

Huff, W. Gregg. 1997. The Economic Growth of Singapore. Cambridge: Cambridge University Press.

Hughes, Caroline. 2009. "Cambodia in 2008: Consolidation in the Midst of Crisis." Asian Survey 49, 1: 206-212.

Huntington, Samuel P. 1991. The Third Wave. Norman: University of Oklahoma Press.

Hutchcroft, Paul D. 1991. "Oligarchs and Cronies in the Philippine State and the Politics of Patrimonial Plunder." World Politics 43, 3: 414-450.

1998. Booty Capitalism: The Politics of Banking in the Philippines. Ithaca: Cornell University Press.

- 2000. "Obstructive Corruption: The Politics of Privilege in the Philippines." In Rents and Rent-seeking and Economic Development: Theory and the Asian Evidence, ed. Mushtaq H. Khan and K. S. Jomo, 207-247. Cambridge: Cambridge University Press.

Hutchcroft, Paul D., and Joel Racamora. 2003. "Strong Demands and Weak Institutions: The Origins and Evolution of the Democratic Deficit in the Philippines." Journal of East Asian Studies 3: 259-292. 
Im, Hyug Baeg. 2004. "Faltering Democratic Consolidation in South Korea: Democracy at the End of the Three Kims Era." Democratization 11, 5: 179-198.

Johnson, Chalmers. 1987. "Political Institutions and Economic Performance: The Government Business Relationship in Japan, Korea and Taiwan." In The Political Economy of the New Asian Industrialism, ed. Frederic C. Deyo, 136-164. Ithaca: Cornell University Press.

Jomo, K. S. 1986. A Question of Class: Capital, the State, and Uneven Development in Malaya. New York: Oxford University Press.

Jomo, K. S., ed. 2001. Southeast Asia's Industrialization: Industrial Policy, Capabilities and Sustainability. London: Palgrave MacMillan.

_ - ed. 2007. Malaysian Industrial Policy. Singapore: Singapore University Press.

Karl, Terry L. 1990. "Dilemmas of Democratization in Latin America." Comparative Politics 23, 1: 1-21.

Khoo, Boo T. 1995. The Paradoxes of Mahathirism. New York: Oxford University Press.

- 2003. Beyond Mahathir: Malaysian Politics and Its Discontents. London: Zed Books.

King, Blair A. 2004. "Empowering the Presidency: Interests and Perceptions in Indonesia's Constitutional Reforms." PhD diss. Columbus: Ohio State University.

King, Daniel E. 1996. "Thailand in 1995: Open Society, Dynamic Economy, Troubled Politics." Asian Survey 36, 2: 135-141.

Kopol, Orathai. 2002. "Electoral Politics in Thailand." In Electoral Politics in Southeast Asia and East Asia, ed. Dieter Nohlen, Gabriele Bruns, and Marei John, 277-320. Singapore: Friedrich Ebert Stiftung.

Laothamatas, Anek, ed. 1997. Democratization in Southeast and East Asia. New York: St. Martin's Press and Institute of Southeast Asian Studies.

Levine, Ross, and David Renelt. 1992. "A Sensitivity Analysis of Cross Country Growth Regressions." American Economic Review 82, 4: 942963.

Liddle, R. William. 1991. "The Relative Autonomy of the Third World Politician: Soeharto and Indonesian Development in Comparative Perspective." International Studies Quarterly 35: 403-427.

Liddle, R. William, and Saiful Mujani. 2006. "Indonesia in 2005: A New Multi-party Presidential Democracy." Asian Survey 46, 1: 132-139.

Lijphart, Arend. 1968. The Politics of Accommodation: Pluralism and Democracy in the Netherlands. Berkeley: University of California Press.

-1977. Democracy in Plural Societies: A Comparative Exploration. New Haven: Yale University Press.

Lim, Hong Hai. 2002. "Electoral Politics in Malaysia: Managing Elections in a Plural Society." In Electoral Politics in Southeast and East Asia, ed. Dieter Nohlen, Gabriele Bruns, and Marei John, 101-148, Singapore: Friedrich Ebert Stiftung.

Lin, Jih-wen. 2006. "Electoral Systems Today: The Politics of Reform in Japan and Taiwan." Journal of Democracy 17, 2: 118-131. 
Ljunggren, B., ed. 1993. The Challenge of Reform in Indo-China. Harvard Institute for International Development. Cambridge: Harvard University Press.

Marshall, Monty G., and Keith Jaggers. 2008. Polity IV Project: Political Regime Characteristics and Transitions, 1800-2008. Center for International Development and Conflict Management. College Park: University of Maryland. Dataset available at www.cidcm.umd.edu/polity.

McCargo, Duncan. 1997. "Thailand's Political Parties: Real, Authentic and Actual." In Political Change in Thailand: Democracy and Participation, ed. Kevin Hewison, 114-131. London: Routledge.

Mietzner, Marcus. 2008. "Comparing Indonesia's Party Systems of the 1950s and the Post-Suharto Era: From Centrifugal to Centripetal Interparty Competition." Journal of Southeast Asian Studies 39, 3: 431-453.

- 2009. "Indonesia in 2008: Yudhoyono's Struggle for Re-election." Asian Survey 49, 1: 146-155.

- 2010. "Indonesia in 2009: Electoral Contestation and Economic Resilience." Asian Survey 50, 1: 185-194.

Montinola, Gabrielle R. 1999. "Parties and Accountability in the Philippines." Journal of Democracy 10, 1: 126-140.

Mujani, Saiful, and R. William Liddle. 2010. "Indonesia: Personalities, Parties, and Voters." Journal of Democracy 21, 2: 35-49.

Muscat, Robert J. 1994. The Fifth Tiger: A Study of Thai Development Policy. New York: M. E. Sharpe.

Mutalib, Hussin. 2002. "Constitutional-electoral Reforms and Politics in Singapore." Legislative Studies Quarterly 27, 4: 659-672.

Naughton, Barry. 2007. The Chinese Economy: Transitions and Growth. Cambridge, MA: MIT Press.

Nohlen, Dieter, Gabriele Bruns, and Marei John, eds. 2002. Electoral Politics in Southeast and East Asia. Singapore: Friedrich Ebert Stiftung.

Nohlen, Dieter, Florian Grotz, and Christof Hartmann, eds. 2001. Elections in Asia and the Pacific: A Data Handbook. Oxford: Oxford University Press.

Papaioannou, Elias, and Gregorios Siourounis. 2008. "Democratization and Growth." Paper downloaded at http://phd.london.edu/epapaioannou.

Pepinsky, Thomas B. 2009. Economic Crises and the Breakdown of Authoritarian Regimes: Indonesia and Malaysia in Comparative Perspective. Cambridge: Cambridge University Press.

Pepinsky, Thomas B., R. William Liddle, and Saiful Mujani. 2012. "Testing Islam's Political Advantage: Evidence from Indonesia." American Journal of Political Science. Published online January 23, 2012. DOI: 10 $.1111 / \mathrm{j} .1540-5907.2011 .00570 . x$.

Persson, Torsten, and Guido Tabellini. 2000. Political Economics: Explaining Economic Policy. Cambridge: MIT Press.

-2005. The Economic Effects of Constitutions. Cambridge: MIT Press. . 2006. "Democracy and Development: The Devil in the Details." American Economic Review 96, 2: 319-324. 
Political Risk Services. 2012. "International Country Risk Guide: ICRG Researchers' Dataset." http://www.prsgroup.com/ICRG.aspx.

Przeworski, Adam, Michael E. Alvfarez, Jose Antonio Cheibub, and Fernando Limongi. 2000. Democracy and Development. Cambridge: Cambridge University Press.

Reilly, Benjamin. 2006. Democracy and Diversity: Political Engineering in the Asian Pacific. Oxford: Oxford University Press.

Rieger, Hans Christoph. 2001. "Singapore." In Elections in Asia and the Pacific: A Data Handbook, ed. Dieter Nohlen, Florian Grotz, and Christof Hartmann, 239-259. Oxford: Oxford University Press.

Rinza, Marianne. 2001. "Taiwan (Republic of China)." In Elections in Asia and the Pacific: A Data Handbook, ed. Dieter Nohlen, Florian Grotz, and Christof Hartmann, 525-570. Oxford: Oxford University Press.

Robinson, Mark, and Gordon White, eds. 1998. The Democratic Developmental State. Oxford: Oxford University Press.

Rock, Michael T. 1994. "Transitional Democracies and the Shift to Exportled Industrialization: Lessons from Thailand." Studies in Comparative International Development 29, 1 (Spring): 18-37.

- 1995. "Thai Industrial Policy: How Irrelevant Was It to Export Success?” Journal of International Development 7, 5: 745-757.

-1999. "Reassessing the Effectiveness of Industrial Policy in Indonesia: Can the Neo-liberals Be Wrong?" World Development 27, 4 (April): 691-704.

- 2000. "Thailand's Old Bureaucratic Polity and Its New Semidemocracy." In Rents and Rent-seeking and Economic Development: Theory and the Asian Evidence, ed. Mushtaq H. Khan and K. S. Jomo, 183-206. Cambridge: Cambridge University Press.

. 2003. "The Politics of Development Policy-making in New Order Indonesia." Working Paper No. 632, November. Ann Arbor: William Davidson Institute, University of Michigan.

Rock, Michael T., and Meagan Sheridan. 2007. "The Political Economy of Industrial Policy in Malaysia." In Malaysian Industrial Policy, ed. K. S. Jomo, 179-221. Singapore: Singapore University Press.

Rodrik, Dani, and Romain Wacziarg. 2005. "Do Democratic Transitions Produce Bad Economic Outcomes?" American Economic Review Papers and Proceedings 95, 2: 50-55.

Shugart, Matthew S., and John M. Carey. 1992. Presidents and Assemblies: Constitutional Design and Electoral Systems. Cambridge: Cambridge University Press.

Slater, Dan. 2004. "Indonesia's Accountability Trap: Party Cartels and Presidential Power After Democratic Transition." Indonesia 78 (October): 61-92.

2008. "Democracy and Dictatorship Do Not Freely Float: Structural Sources of Political Regimes in Southeast Asia." In Southeast Asia in Political Science: Theory, Region and Qualitative Analysis, ed. Erik M. Kuhonta, Dan Slater, and Tuong Vu, 55-79. Stanford: Stanford University Press. 
Staiger, Douglas, and James H. Stock. 1997. "Instrumental Variables Regression with Weak Instruments." Econometrica 68: 1055-1096.

Strom, Kaare. 2002. "Delegation and Accountability in Parliamentary Democracies." European Journal of Political Research 37: 261-289.

Strom, Kaare, Wolfgang C. Muller, and Torbjorn Bergman, eds. 2006. Delegation and Accountability in Parliamentary Democracies. New York: Oxford University Press.

Sulistyo, Hermawan. 2002. "Electoral Politics in Indonesia: A Hard Way to Democracy." In Electoral Politics in Southeast and East Asia, ed. Dieter Nohlen, Gabriele Bruns, and Marei John, 75-99. Singapore: Friedrich Ebert Stiftung.

Tan, Paige Johnston. 2002. "Anti-party Reaction in Indonesia: Causes and Implications." Contemporary Southeast Asia 24, 3: 484-508.

Teehankee, Julio. 2002. "Electoral Politics in the Philippines." In Electoral Politics in Southeast and East Asia, ed. Dieter Nohlen, Gabriele Bruns, and Marei John, 149-202. Singapore: Friedrich Ebert Stiftung.

Thak, Chaloemtiarana. 2007. Thailand: The Politics of Despotic Paternalism. Ithaca, NY: Southeast Asia Program, Cornell University.

Thoburn, John. 2009. "Vietnam as a Role Model for Development." UNUWIDER Research Paper No. 2009/30, May. Helsinki, Finland.

Ufen, Andreas. 2008. "Political Party and Party System Institutionalization in Southeast Asia: Lessons for Democratic Consolidation in Indonesia, the Philippines, and Thailand." The Pacific Review 21, 3: 327-350.

Van Arkadie, Brian, and Raymond Mallon. 2003. Vietnam: A Transition Tiger. Canberra: ANU E Press.

Van de Walle, Nicholas. 2001. African Economies and the Politics of Permanent Crisis, 1979-1999. Cambridge: Cambridge University Press.

Wade, Robert H. 1990. Governing the Market. Princeton: Princeton University Press.

Walker, Scott, and Kyung-Tae Kang. 2002. "The Presidential Election in South Korea." Electoral Studies 23, 4 (December): 840-845.

Webber, Douglas. 2006. "A Consolidated Patrimonial Democracy? Democratization in Post-Suharto Indonesia." Democratization 13, 3: 396-420.

White, Gordon. 2006. "Towards a Democratic Developmental State." IDS Bulletin 37, 4: 60-70.

Woo, Jung-en. 1991. Race to the Swift: State and Finance in Korean Industrialization. New York: Columbia University Press.

World Bank. 1993. The East Asian Miracle. Oxford: Oxford University Press. - 2012. World Development Indicators. http://databank.worldbank.org .proxy.brynmawr.edu/Data/Views/VariableSelection/SelectVariables .aspx? source $=$ World\%20Development\%20Indicators.

Yeo, Lay Hwee. 2002. "Electoral Politics in Singapore." In Electoral Politics in Southeast and East Asia, ed. Dieter Nohlen, Gabriele Bruns, and Marei John, 203-232. Singapore: Friedrich Ebert Stiftung.

Young, Alwyn. 1995 "The Tyranny of Numbers: Confronting the Statistical Realities of the East Asian Growth Experience." Quarterly Journal of Economics 110: 640-680. 